\title{
Mapping of Endogenous Morphine-Like Compounds in the Adult Mouse Brain: Evidence of Their Localization in Astrocytes and GABAergic Cells
}

\author{
Alexis Laux, ${ }^{1,2}$ Arnaud H. Muller, ${ }^{2}$ Monique Miehe, ${ }^{1,3}$ Sylvie Dirrig-Grosch, ${ }^{4}$ Jean Christophe Deloulme, ${ }^{5}$ \\ François Delalande, ${ }^{6}$ Denise Stuber, ${ }^{1}$ Dominique Sage, ${ }^{7}$ Alain Van Dorsselaer, ${ }^{6}$ Pierrick Poisbeau, ${ }^{1}$ \\ Dominique Aunis, ${ }^{2}$ and Yannick Goumon ${ }^{1,2 *}$ \\ ${ }^{1}$ Nociception and Pain Department, Institut des Neurosciences Cellulaires et Intégratives, CNRS UPR 3212 and Université de \\ Strasbourg, F-67084 Strasbourg, France \\ ${ }^{2}$ INSERM, U575, Physiopathologie du Système Nerveux, F-67084 Strasbourg, France \\ ${ }^{3}$ Plateforme imagerie cellulaire Strasbourg esplanade (Plateforme d'imagerie in vitro), IFR37 Neurosciences, F-67084 Strasbourg, \\ France \\ ${ }^{4}$ INSERM, U692, Laboratoire de signalisations moléculaires et neurodégénérescence, Université de Strasbourg UMRS692, F-67084 \\ Strasbourg, France \\ ${ }^{5}$ INSERM, U866, Institut des Neurosciences, CEA/IRTSV/GPC, Université Joseph Fourrier, F-38042 Grenoble, France \\ ${ }^{6}$ Laboratoire de spectrométrie de masse BioOrganique, IPHC-DSA, Université de Strasbourg, CNRS UMR7178, F-67087 Strasbourg, \\ France \\ ${ }^{7}$ Plate-forme d'hébergement et d'exploration fonctionnelle Chronobiotron, IFR37 Neurosciences -CNRS, F-67084 Strasbourg, \\ France
}

\begin{abstract}
Endogenous morphine, morphine-6-glucuronide, and codeine, which are structurally identical to vegetal alkaloids, can be synthesized by mammalian cells from dopamine. However, the role of brain endogenous morphine and its derivative compounds is a matter of debate, and knowledge about its distribution is lacking. In this study, by using a validated antibody, we describe a precise mapping of endogenous morphine-like compounds (morphine and/ or its glucuronides and/or codeine) in the mouse brain. First, a mass spectrometry approach confirmed the presence of morphine and codeine in mouse brain, but also, of morphine-6-glucuronide and morphine-3-glucuronide representing two metabolites of morphine. Second, light microscopy allowed us to observe immunopositive cell somas and cytoplasmic processes throughout the mouse brain. Morphine-like immunoreactivity was present in various structures including the hippocampus, olfactory bulb, band of
\end{abstract}

Additional Supporting Information may be found in the online version of Grant sponsors: Institut National de la Santé et de la Recherche Médicale (INSERM); Centre National de la Recherche Scientifique (CNRS); Université de Strasbourg; French Ministère délégué à la Recherche et à

*CORRESPONDENCE TO: Dr. Yannick Goumon, INCI, CNRS UPR3212, 5, rue Blaise Pascal, F-67084 Strasbourg Cedex, France. E-mail: yannick.

Received December 23, 2009; Revised August 20, 2010; Accepted March 1,2011

DOI 10.1002/cne.22633

Published online March 31, 2011 in Wiley Online Library (wileyonlinelibrary.com)

(C) 2011 Wiley-Liss, Inc.
Broca, basal ganglia, and cerebellum. Third, by using confocal microscopy and immunofluroscence co-localization, we characterized cell types containing endogenous opiates. Interestingly, we observed that morphine-like immunoreactivity throughout the encephalon is mainly present in $\gamma$-aminobutyric acid (GABA)ergic neurons. Astrocytes were also labeled throughout the entire brain, in the cell body, in the cytoplasmic processes, and in astrocytic feet surrounding blood vessels. Finally, ultrastructural localization of morphine-like immunoreactivity was determined by electron microscopy and showed the presence of morphinelike label in presynaptic terminals in the cerebellum and postsynaptic terminals in the rest of the mouse brain. In conclusion, the presence of endogenous morphine-like compounds in brain regions not usually involved in pain modulation opens the exciting opportunity to extend the role and function of endogenous alkaloids far beyond their analgesic functions. J. Comp. Neurol. 519:2390-2416,

this article.

l'Enseignement Supérieur (Ph.D. fellowship to A.M. and A.L.); Fondation Transplantation (to Y.G.); Fondation pour la Recherche Médicale (to Y.G.).

goumon@inserm.u-strasbg.fr 
2011. (c) 2011 Wiley-Liss, Inc.

INDEXING TERMS: morphine; morphine-6-glucuronide; morphine-3-glucuronide; codeine; dopamine; immunohistochemistry

\section{INTRODUCTION}

Morphine extracted from Papaver somniferum remains the gold standard for pain relief in the hospital setting (Stefano et al., 2000; Soliman et al., 2001). This alkaloid binds to the $\mu$-opioid receptor (MOR), leading to several effects, including analgesia (Matthes et al., 1996). In humans, exogenous morphine is mainly catabolized into morphine-6-glucuronide (M6G;10\%) and morphine-3-glucuronide (M3G; 90\%) through the action of the UDP-glucuronosyltransferase $1 \mathrm{~A}$ and $2 \mathrm{~B}$ families (UGT1A and UGT2B), which are present in the liver (Mackenzie et al., 2005) and in the brain (Suleman et al., 1998; Nagano et al., 2000; Heurtaux et al., 2006). M6G displays greater analgesic effects than morphine, whereas M3G is devoid of analgesic effects (Lotsch and Geisslinger, 2001; Lotsch, 2005a,b; Coller et al., 2009).

Since the 1970s, endogenous morphine, M6G, and codeine, which are structurally identical to alkaloids from plants, have been characterized in different mammalian tissues and cells (Gintzler et al., 1978; Hazum et al., 1981; Goldstein et al., 1985; Weitz et al., 1986; Donnerer et al., 1987; Herbert et al., 2000; Stefano et al., 2000, 2008; Zhu et al., 2001; Neri et al., 2004; Goumon et al., 2009). In mammals, the endogenous morphine biosynthesis pathway has been studied in the SH-SY5Y human neuronal catecholaminergic cell line and has been shown to derive from the dopamine biosynthesis pathway, leading to codeine and finally to morphine (Poeaknapo et al., 2004; Boettcher et al., 2005; Muller et al., 2008; Stefano et al., 2008). In addition, blockade of the dopamine biosynthesis using a tyrosine hydroxylase (TH) conditional knockdown mouse model is associated with a deficit in endogenous morphine synthesis (Neri et al., 2008), suggesting that dopamine is a precursor of endogenous morphine in mammalian cells. However, because the non-dopaminergic cell line DAN-G produces morphine (Poeaknapo et al., 2004), it is possible that non-dopaminergic cells can internalize dopamine or intermediate metabolites of the morphine biosynthesis pathway, such as tetrahydropapaveroline (THP; also called norlaudanosoline), but also synthesize intermediate metabolites for morphine biosynthesis, to complete the production of endogenous morphine (Boettcher et al., 2005; Goumon et al., 2009; Grobe et al., 2010).

We have previously reported the presence of M6G in secretory granules and secreted material of bovine adrenal chromaffin cells (Goumon et al., 2006). M6G was associated with the phosphatidylethanolamine-binding protein (PEBP), a protein that specifically binds M6G and M3G and has no affinity for morphine (Goumon et al., 2004; Atmanene et al., 2009). In these particular cells, we observed the presence of an UGT2B-like enzyme able to convert morphine into M6G. More recently, in the $\mathrm{SH}-$ SY5Y cell line model, we observed the presence of morphine and $M 6 G$ and characterized the presence of UGT2B7, which has been shown to catabolize morphine to M3G and M6G (Coffman et al., 1997; Muller et al., 2008). M6G, despite its more potent analgesic nature, was previously thought of only as a product of morphine catabolism. However, our data have indicated that M6G may represent the final product of endogenous alkaloid biosynthesis in chromaffin cells, whereas in SH-SY5Y cells, both morphine and M6G coexist (Muller et al., 2008).

The presence of endogenous morphine, codeine, and M6G has been characterized in the brain of cows, rats, monkeys, mice, and dogs (Donnerer et al., 1987; Stefano et al., 2000; Goumon et al., 2009). Recent data have indicated that high endogenous morphine levels are present in the blood during stressful situations including pathological states such as sepsis (Brix-Christensen et al., 1997, 2000; Glattard et al., 2010; Madbouly et al., 2010). However, these fluctuations in morphine levels and their consequences for brain function remain to be fully elucidated (Goumon et al., 2009). Among the few available studies, it has been shown that endogenous morphine immunoneutralization (intracerebroventricular administration of an anti-morphine antibody) decreased thermal response latency and attenuated the anti-nociceptive effect of the MOR-selective agonist DAMGO in a hot plate test. This suggests that endogenous morphine is involved in the setting of nociceptive thresholds and in opiate-mediated pain modulation (Guarna et al., 2002). A similar immunoneutralization approach has suggested a role for endogenous morphine in the weakening of memory processes under stressful conditions (Guarna et al., 2004).

Our recent studies have focused on the functional role of endogenous morphine in neuronal cells. Using the SH-SY5Y model, morphine and M6G were found to be restricted to large, dense-core vesicle-like organelles and to be released via a $\mathrm{Ca}^{2+}$-dependent mechanism (Muller et al., 2008). Using the patch-clamp technique in cell culture, we have shown that naloxone-sensitive electrophysiological responses are induced by morphine and M6G at concentrations as low as $10^{-10} \mathrm{M}$. Using the mouse brain model, we have shown well-defined morphine expression 
TABLE 1.

Primary Antibodies Used

\begin{tabular}{|c|c|c|c|c|}
\hline Antigen & Immunogen & Raised in & Manufacturer data & Dilution \\
\hline GAD65/67 & $\begin{array}{l}\text { Synthetic peptide corresponding to } \\
C^{\text {ter }} \text { part of human GAD. The } \\
\text { sequence is identical in human } \\
\text { GAD65 (amino acids 570-585) and } \\
\text { GAD67 (amino acids 579-594) } \\
\text { (Peptide: K-DIDFLIEEIERLGQDL) }\end{array}$ & Rabbit (polyclonal) & Abcam (ab49832) & IHC: $1: 500$ \\
\hline GFAP & GFAP isolated from cow spinal cord & Rabbit (polyclonal) & DAKO (Z0334) & IHC: $1: 1,000$ \\
\hline TH & $\begin{array}{l}\text { Denatured TH from rat } \\
\text { pheochromocytoma }\end{array}$ & Rabbit (polyclonal) & Chemicon-Millipore (AB152) & IHC: $1 ; 1,000$ \\
\hline Morphine & BSA-morphine conjugate & Mouse (monoclonal) & Aviva Systems Biology (AVAMM16002-4) & $\begin{array}{l}\text { IHC: } 1: 1,000 \\
\text { ICC: } 1: 3,000 \\
\text { WB: } 1: 4,000 \\
\text { ELISA: } 1: 2,000\end{array}$ \\
\hline
\end{tabular}

Abbreviations: GAD, glutamic acid decarboxylase; GFAP, glial fibrillary acidic protein; TH, tyrosine hydroxylase; BSA, bovine serum albumin; IHC, immunohistochemistry; ICC, immunocytochemistry; WB, Western blot; ELISA, enzyme-linked immunosorbent assay.

in the cerebellum, with morphine immunoreactivity present in basket cell bodies and in their axonal synaptic terminals, which innervate Purkinje cell bodies that express MOR subtypes (Mrkusich et al., 2004; Zhang et al., 2006; Muller et al., 2008). Morphine immunoreactivity was also present at the presynaptic level, suggesting its possible release and a regulatory action on Purkinje cell function (Muller et al., 2008; Goumon et al., 2009). This is supported by the previously published description of $\mathrm{Ca}^{2+}$ dependent release of morphine from nerve terminals (Guarna et al., 1998). Other studies have also shown the presence of morphine and codeine in specific brain neurons (Gintzler et al., 1978; Bianchi et al., 1993, 1994). This further suggests that endogenous morphine and its derivatives may represent new neuromodulators of brain functions, acting at both pre- and postsynaptic sites within neuronal networks.

A straightforward approach to studying the roles of endogenous morphine and morphine-derived molecules in brain physiology is to examine in detail their localization in brain structures. Few data are available on the localization of endogenous morphine, morphine glucuronides, or codeine in the central nervous system (CNS), and no precise mapping exists. The present study was designed to determine morphine/M3G/M6G/codeine immunoreactivity in mouse brain structures. First, a biochemical approach was used to characterize the presence of morphine, morphine glucuronides, and codeine in the mouse brain. Second, detailed immunohistochemical mapping of endogenous morphine-like compounds (i.e., morphine, M6G, M3G, and codeine) in the adult mouse brain was performed by using conventional and confocal microscopy and electron microscopy, to determine subcellular localizations. Finally, co-immunolocalization of morphinelike immunoreactivity with different cell markers allowed us to characterize cells that contain endogenous morphine and/or morphine-derived molecules.

\section{MATERIALS AND METHODS}

\section{Animals}

Experiments were performed on five 45-day-old laboratory-bred, adult male C57BL/ 6 mice weighting $30 \pm 3 \mathrm{~g}$. Animals were given free access to food and water, with a 12-hour light-dark cycle at a temperature of $22 \pm 2^{\circ} \mathrm{C}$. All procedures were performed in accordance with European directives (86/609/EEC) and were approved by the regional ethics committee and the French Ministry of agriculture (license no. 67-116, to P.P.).

\section{Antibody characterization}

Antibodies used in the present study are commercially available and have already been used in previous studies. Table 1 provides informations about these antibodies including immunogens, species, commercial sources, and dilutions used in the present study.

\section{Glutamic acid decarboxylase isoforms 65/67 (GAD65/67) antibody}

The rabbit anti-GAD65/67 antiserum (Abcam, Cambridge, MA; \#ab49832) was produced by using one synthetic peptide common to the two GAD isoforms. AntiGAD65/67 antibodies recognize a specific band size of $65 \mathrm{kDa}$ molecular weight on Western blot of human infant medulla lysate (Broadbelt et al., 2010). The staining observed on Western blot was blocked when incubation with the peptide was performed. In immunohistochemistry on mouse brain sections, no immunostaining was observed after a pre-incubation of the antibody with saturating concentration of the target protein (Broadbelt et al., 2010). 


\section{Glial fibrillary acidic protein (GFAP) antibody}

The rabbit anti-GFAP polyclonal antiserum (DAKO, Glostrup, Denmark; \#Z0334) was produced by using GFAP isolated from cow spinal cord. The staining pattern by immunohistochemistry matches the expected distribution of GFAP in mouse auditory brainstem (Abraira et al., 2007). With the use of cultured mouse primary astrocytes, the antibody staining demonstrates a filamentous pattern, consistent with GFAP presence in intermediate filaments. In Western blot using mouse brain extracts, this antibody recognizes a band of approximately $55 \mathrm{kDa}$ (Arantes et al., 2009).

\section{Tyrosine hydroxylase (TH) antibody}

The rabbit anti-TH polyclonal antiserum (ChemiconMillipore, Molsheim, France; \#AB152) was produced by using denatured full-length $\mathrm{TH}$ isolated from rat pheochromocytoma. Its specificity has been corroborated by Western blot analysis of adrenal gland or brain of different species (i.e. rat, mouse; see manufacturer's data sheet), in which it selectively labels a single band at approximately $62 \mathrm{kDa}$. In addition, a selective label of dopaminergic neurons in the substantia nigra pars compacta has been observed (Martin-lbanez et al., 2006).

\section{Morphine antibody}

The mouse anti-morphine antibody (6D6, Aviva Systems Biology, San Diego, CA; \# 16002) was produced by using a morphine-bovine serum albumin (BSA) conjugate. This antibody has been used in previous studies (Muller et al., 2008; Glattard et al., 2010) to determine the presence of morphine/M6G by immunohistochemistry, with results consistent with those described here (i.e. basket cell labeling in cerebellar cortex). Furthermore, seven specificity controls for the anti-morphine antibody (6D6) were performed for this study:

1. The morphine antibody was omitted in order to control for nonspecific binding of the secondary antibody in the tissue section. Omission of the primary antibody resulted in no peroxidase label in the tissue sections (e.g., striatum) compared with 6D6 immunoreactivity (data not shown).

2. Immunoreactivity disappeared when the 6D6 antibody was preabsorbed for 1 hour with $3 \mu \mathrm{M}$ of morphine (Sigma-Aldrich, St. Louis, MO), codeine (SigmaAldrich), M6G (Sigma-Aldrich), or M3G (Sigma-Aldrich; data not shown) before immunohistochemistry.

3. Western blotting of mouse brain extracts with the 6D6 antibody was performed and showed no crossreactivity of the antibody with proteins (see Results, Fig. 3C, lane 1).

4. A control for the cross-linking of morphine, M6G,
$M 3 G$, and codeine to proteins by paraformaldehyde (PFA) was performed in vitro (see Results, Fig. 3B,C, lane 2) and in vivo (see Results).

5. We assessed 6D6 anti-morphine antibody cross-reactivity with morphine, morphine derivatives, and catecholamines by enzyme-linked immunosorbent assay (ELISA; see Results, Fig. 2). The 6D6 antibody is only able to recognize morphine, codeine, M6G, and M3G.

6. To link the immunohistochemistry results described in this study and the biochemical detection of endogenous morphine, codeine, M3G, and M6G, we performed mass spectrometry analysis of micropunches from several brain areas. No endogenous alkaloids have been detected in structures that are poorly immunoreactive, such as the amygdala nuclei and the VPL/VPN nucleus of the thalamus; however, we were able to detect codeine in strongly immunoreactive structures, such as the caudate putamen (2.89 $\mathrm{fmol} / \mathrm{mg}$ protein), the olfactory bulb $(2 \mathrm{fmol} /$ $\mathrm{mg}$ protein), and the cortex $(0.62 \mathrm{fmol} / \mathrm{mg}$ protein). The levels of morphine, M6G, and M3G were beneath the limit of detection in these brain areas.

7. Immunoprecipitation was performed to confirm the ability of the 6D6 antibody to bind endogenous alkaloid. Thus, $10 \mathrm{mg}$ of whole mouse brain extract (in $400 \mu$ of phosphate-buffered saline [PBS], $\mathrm{pH}$ 7.4) were mixed with $20 \mu \mathrm{g}$ of the 6D6 antibody and incubated overnight at $4^{\circ} \mathrm{C}$. The reaction medium was then incubated with $300 \mu$ l of protein A/G PLUS-agarose beads (Santa Cruz Biotechnology, Santa Cruz, CA; \#sc-2003) and incubated for 4 hours at $4^{\circ} \mathrm{C}$. Complexes (i.e., antibodies-alkaloids-beads) were washed five times with $500 \mu \mathrm{l}$ of PBS $\left(4^{\circ} \mathrm{C}\right)$. Elution of the protein A/G-mouse IgG complex was done by boiling for 30 minutes in a $1 \mathrm{M}$ urea buffer. After acidification with $1 \mathrm{M} \mathrm{HCl}$, an equal volume of chloroform was added. The mixture was then centrifuged at 13,000 rpm for 15 minutes at $4^{\circ} \mathrm{C}$. The aqueous phase was retrieved and submitted to LC-MS/MS analysis (see below). Codeine $(17.1 \mathrm{fmol})$ and morphine $(6.3 \mathrm{fmol})$ were detected in the immunoprecipitated fraction, confirming the presence of these alkaloids and the ability of the 6D6 antibody to detect them in the mouse brain.

\section{Immunohistochemistry Tissue preparation for immunohistochemistry studies}

Mice were deeply anesthetized by intraperitoneal injection of $0.1 \mathrm{ml}$ of a $5.6 \%(\mathrm{w} / \mathrm{v})$ pentobarbital sodium solution (CEVA Santé Animale, Libourne, France) and perfused transcardially with fixative solution using a peristaltic 
pump. For conventional and electron microscopy, a fixative solution of $4 \%$ formaldehyde (EMS, Hatfield, PA) in a $0.1 \mathrm{M}$ $\mathrm{NaCl} / \mathrm{Pi}$ buffer (disodium hydrogen phosphate dihydrate, $1.28 \%[\mathrm{w} / \mathrm{v}]$, sodium dihydrogen phosphate monohydrate, $0.38 \%[\mathrm{w} / \mathrm{v}] ; \mathrm{pH} 7.4)$ with $0.25 \%(\mathrm{v} / \mathrm{v})$ glutaraldehyde (VWR, Fontenay sous bois, France) was used. The same fixative solution was used for laser confocal microscopy, except that glutaraldehyde was omitted. Fixative solutions were chilled and then perfused for 10 minutes with a peristaltic pump at a flow rate of $10 \mathrm{ml} / \mathrm{min}$. The brain was quickly removed and incubated for 2 hours at $4^{\circ} \mathrm{C}$ in the same fixative solution. Coronal and sagittal brain sections (70 $\mu \mathrm{m}$ thick) were cut with a Vibratome (Leica VT $1000 \mathrm{~S}$, Nanterre, France) and collected in Tris-buffered saline (TBS: $50 \mathrm{mM}$ Tris- $\mathrm{HCl}, 0.9 \% \mathrm{NaCl}, \mathrm{pH} 7.4$ ).

\section{Slice immunostaining}

Immunostaining was performed on slides, free-floating in TBS, as previously described (Hedou et al., 2000). Tissue slices were washed in TBS and incubated for 1 hour in BSA (Euromedex, Mundolsheim, France) diluted in TBS $(5 \%, \mathrm{w} / \mathrm{v})$ in order to saturate nonspecific immunoreactive sites. After saturation, sections were incubated overnight with a mixture of primary antibodies raised in different species in TBS containing $0.1 \%(\mathrm{v} / \mathrm{v})$ Triton X-100 (Sigma-Aldrich). Triton X-100 was omitted for electron microscopy. Primary antibodies were used as described in the antibody list in Table 1. After incubation with the primary antibody, tissue slices were washed six times with TBS (5 minutes), and specific secondary antisera were added for 2 hours at room temperature (RT), followed by six TBS washes (5 minutes). These secondary antisera were as follows: 1) horseradish peroxidase (HRP)-conjugated donkey anti-mouse IgG (P.A.R.I.S., Paris, France; \#BI 2413C; dilution 1:400); 2) Alexa Fluor 488-conjugated donkey anti-rabbit IgG (Molecular Probes-Invitrogen, Cergy Pontoise, France; \#A2 1206; dilution 1:1,000); and 3) Cy3-conjugated donkey anti-mouse IgG (Jackson ImmunoResearch, Suffolk, England; \#715-165-150; dilution 1:1,000). Several controls were carried out to assess antibody specificity and nonspecific immunoreactivity. Primary antibodies were omitted, and each secondary antibody was tested individually or in a mixture in the presence of tissue sections. Each antibody was also tested with the secondary antibody used for the second immunolabeling in order to determine whether interspecies cross-reactivity exists.

\section{Light microscopy}

Peroxidase activity was measured after a 15 minutes incubation period in a freshly prepared solution of 4chloro-1-naphthol $(0.2 \mathrm{mg} / \mathrm{ml})$ in TBS containing $0.006 \%$ $(\mathrm{w} / \mathrm{v})$ hydrogen peroxide. After washing with TBS, the sections were mounted in glycerol/TBS $(1: 1, \mathrm{v} / \mathrm{v})$ before analysis with a Leica DMRB microscope equipped with a digital camera (Axiocam, Zeiss, Le Pecq, France).

\section{Electron microscopy}

Peroxidase activity was detected with a freshly prepared solution of $0.025 \%(\mathrm{w} / \mathrm{v})$ 3,3-diaminobenzidine tetrahydrochloride in TBS containing $0.006 \%(\mathrm{w} / \mathrm{v})$ hydrogen peroxide. After washing with $\mathrm{NaCl} / \mathrm{Pi}$ buffer, sections and slides were postfixed for 30 minutes with $2.5 \%$ glutaraldehyde in $0.1 \mathrm{M} \mathrm{NaCl} / \mathrm{Pi}$ buffer ( $\mathrm{pH} 7.4)$, and then with $1 \%$ $(\mathrm{w} / \mathrm{v})$ osmium tetroxide in $0.1 \mathrm{M} \mathrm{NaCl} / \mathrm{Pi}$ buffer $(\mathrm{pH} 7.4)$ at $4^{\circ} \mathrm{C}$ for 1 hour. Sections were dehydrated in ethanol and embedded in Araldite resin (Hedou et al., 2000). Ultrathin sections were observed with a Hitachi H 7500 electron microscope (Hitachi, Monroeville, PA) without additional staining. Pictures were acquired with a Hamamatsu Digital camera (C 4742-95, Massy, France).

\section{Confocal microscopy observations}

Immunofluorescent staining was analyzed with a Zeiss laser scanning microscope (LSM510 invert) equipped with a plan apo $63 \times$ oil immersion and a $40 \times$ oil immersion lens. Tissue sections were subjected to optical serial sectioning to produce images in the X-Y plane. Images of optical sections were the average of eight scans. Pictures were recorded digitally in a $1,024 \times 1,024$-pixel format. A look-up table (Range indicator, Zeiss) ensured that the full dynamic range of the photomultipliers was used. Before each measurement, a series of sections was acquired through the vertical axis in order to choose the equatorial section.

\section{Anatomical and cellular distribution}

Anatomical structures were identified under direct observation using the atlas and nomenclature of Paxinos and Watson (Paxinos and Franklin, 1997). Cartography was done on four animals, the staining being identical for each experiment.

\section{HPLC-MS/MS instrumentation and analytical conditions}

A hydrophilic interaction liquid chromatographic (HILIC) reverse phase column coupled to a triple quadrupole mass spectrometer was used to accurately detect the presence of morphine, M3G, and M6G in the selected reaction monitoring (SRM) mode. Identification of the compounds was based on the precursor ion, the selective fragment ions, and retention times.

Prior to LC-MS-MS analysis, methanol-extracted brains were dissolved in $0.1 \%$ trifluoroacetic acid in $\mathrm{H}_{2} \mathrm{O}(\mathrm{v} / \mathrm{v})$ and purified by using an Äkta purifier HPLC system (GE 
Healthcare Bioscience, Strasbourg, France) as previously described (Goumon et al., 2006). Buffer A was $0.1 \%$ trifluoroacetic acid (TFA, v/v) in water, and buffer $B$ was $70 \%$ acetonitrile and $0.09 \%$ TFA in water. Fractions corresponding to morphine, M3G, and M6G were dried by using a SpeedVac evaporator prior to LC-MS-MS analysis. LC retention time of endogenous morphine present in mouse brain was identical to the exogenous morphine standard (external and internal standards).

LC-MS separations were carried out with an Agilent LC 1100 binary pump, equipped with an autosampler, a vacuum degasser, and a column oven coupled with an Agilent 6410 Triple Quad LC/MS (Agilent Technologies, Palo Alto, CA).

Dry samples were resolvated in $10 \mu \mathrm{l}$ of $70 \%$ acetonitrile, vortex-mixed for 1 minute, and injected on an acrylamido-type column (TSKgel Amide-80, TOSOH, Tokyo, Japan) at $25^{\circ} \mathrm{C}$. The solvent system consisted of $99.85 \%$ water, $0.15 \%$ formic acid, and $5 \mathrm{mM}$ ammonium acetate (NH OAc, solvent A) and $100 \%$ acetonitrile (solvent B). Elution was performed at a flow rate of $220 \mu \mathrm{l} / \mathrm{min}$ by using a $70-40 \%$ linear gradient (solvent B) for the first 8 minutes, followed by a $80 \%$ stage (solvent B) for 2 minutes before the reconditioning of the column at $70 \%$ of solvent B. The system was fully controlled by MassHunter software (Agilent Technologies, Santa Clara, CA).

Electrospray ionization was achieved in the positive mode with the spray voltage set at 4,000 V. Nitrogen was used as the nebulizer gas, and nebulizer pressure was set at $20 \mathrm{psi}$ with a source temperature of $100^{\circ} \mathrm{C}$. Desolvation gas (nitrogen) was heated to $350^{\circ} \mathrm{C}$ and delivered at a flow rate of $10 \mathrm{~L} / \mathrm{min}$. Qualification was performed in MRM mode with the following transitions:

$$
\begin{aligned}
& \mathrm{m} / \mathrm{z} 286.1 \rightarrow 201.1 \mathrm{~m} / \mathrm{z} \text { and } 286.1 \rightarrow 165.1 \text { for } \\
& \text { morphine } \\
& \mathrm{m} / \mathrm{z} 462.1 \rightarrow 286.1 \text { and } \mathrm{m} / \mathrm{z} 462.1 \rightarrow 201.1 \text { for M6G } \\
& \text { and } \mathrm{M} 3 \mathrm{G} \\
& \mathrm{m} / \mathrm{z} 300.2 \rightarrow \mathrm{m} / \mathrm{z} 225, \mathrm{~m} / \mathrm{z} 300.2 \rightarrow 214.8, \mathrm{~m} / \mathrm{z} \\
& 300.2 \rightarrow 199.0, \mathrm{~m} / \mathrm{z} 300.2 \rightarrow 164.8 \text {, and } \mathrm{m} / \mathrm{z} 300.2 \\
& \rightarrow 123.0 \text { for codeine. }
\end{aligned}
$$

\section{Anti-morphine 6D6 competitive immunoenzymatic ELISA}

Determination of the morphine 6D6 antibody specificity was done on a 96-well plate (NUNC, Roskilde, Denmark) coated during a night at RT with $200 \mu \mathrm{l}$ of a 100 $\mathrm{ng} / \mathrm{ml}$ morphine-BSA solution (\#80-IM50, Fitzgerald Industries, North Acton, MA). After three washes with $0.1 \mathrm{M} \mathrm{NaCl} / \mathrm{Pi}-0.05 \%$ Tween buffer (PT; 10 minutes), wells were incubated for 1 hour with $200 \mu \mathrm{l}$ of BSA diluted in $\mathrm{NaCl} / \mathrm{Pi}$ buffer $(5 \%, \mathrm{w} / \mathrm{V})$ in order to saturate nonspecific sites. After saturation, wells were incubated for 30 minutes with $100 \mu \mathrm{l}$ of $\mathrm{NaCl} / \mathrm{Pi}-\mathrm{BSA}(3 \%, \mathrm{w} / \mathrm{v})$ containing from $0.01 \mathrm{nM}$ to $1 \mu \mathrm{M}$ of the following potential antigens: morphine (Sigma-Aldrich), M6G (Sigma-Aldrich), M3G (Sigma-Aldrich), codeine (Sigma-Aldrich), norepinephrine (Sigma-Aldrich), epinephrine (Sigma-Aldrich), dopamine (Sigma-Aldrich), L-3,4-dihydroxyphenylalanine (L-DOPA; Sigma-Aldrich), 3,4-dihydroxyphenylacetic acid (DOPAC; Sigma-Aldrich), and norlaudanosoline (THP, Sigma-Aldrich). Then $100 \mu \mathrm{l}$ of the mouse monoclonal primary antibody (6D6, Aviva Systems Biology; dilution $1: 2,000)$ in $\mathrm{NaCl} / \mathrm{Pi}-\mathrm{BSA}(3 \%, \mathrm{w} / \mathrm{v})$ were added to each well. After 3 hours of incubation at RT, the plate was washed three times with PT buffer, and $200 \mu \mathrm{l}$ of the secondary antibody (HRP-conjugated donkey anti-mouse IgG, P.A.R.I.S.; dilution 1:400) was added and left in the wells for 2 hours at RT. After two washes with PT buffer followed by two washes with a $\mathrm{pH} 7.5$ phosphate-citrate$0.05 \%$ Tween buffer (CT; 10 minutes), revelation was performed with $200 \mu \mathrm{l}$ of a fresh solution of ortho-phenylene diamine (OPD; Sigma Aldrich) at $1.5 \mathrm{mg} / \mathrm{ml}$ in CT buffer containing $0.075 \%$ hydrogen peroxide. After 20 minutes of incubation at RT, optical density was determined at $450 \mathrm{~nm}$ with a Multiskan EX plate reader (Thermo Life Sciences, Cergy Pontoise, France). The dissociation constants $(K)$ of the antibody for an antigen were determined by sigmoidal fitting (KyPlot 2.0, Tokyo, Japan).

\section{Cross-binding of morphine and derivatives to proteins after PFA treatment In vivo experiments}

To determine whether alkaloids can be fixed in brain tissues, mice were perfused with 4\% PFA for either 30 minutes (saline, morphine, codeine) or 1 hour (M3G/ M6G) after saline or alkaloid intracerebroventricular (i.c.v.) injections. Brains were used for immunohistochemistry experiments using the 6D6 antibody as described above.

\section{In vitro experiments}

Two different in vitro experiments were performed: 1) $10 \mu \mathrm{g}$ of morphine, codeine, M6G, or M3G were incubated ( 12 hours at $4^{\circ} \mathrm{C}$, under shaking) in the presence of $200 \mu \mathrm{g}$ BSA (BSA V Fraction; Euromedex, Souffelweyersheim, France) and $200 \mu \mathrm{l}$ of $4 \%$ formaldehyde (EMS) in a $0.1 \mathrm{M} \mathrm{NaCl} / \mathrm{Pi}$ buffer; and 2) $200 \mu \mathrm{g}$ of whole protein extract from brain mouse were incubated (12 hours at $4^{\circ} \mathrm{C}$, under shaking) in the presence of $200 \mu \mathrm{l}$ of $4 \%$ formaldehyde (EMS) in a $0.1 \mathrm{M} \mathrm{NaCl} /$ Pi Buffer.

In both experiments, PFA was omitted in control. Then $10 \mu \mathrm{g}$ of protein of the resulting reactions were assayed on Western blot. 


\section{Intracerebroventricular injections}

Mice were anesthetized (i.p.) with a mixture of ketamine (100 mg/kg) and xylazine (10 mg/kg). Following induction of anesthesia, each mouse was placed in a stereotaxic frame. The injection site was $2.6 \mathrm{~mm}$ from the surface of the cortex and $1 \mathrm{~mm}$ to the right of the reference bregma, using coordinates from a standard mouse brain stereotaxic atlas (Paxinos and Franklin, 1997). Then $20 \mathrm{nmol}(5 \mu \mathrm{l})$ of each drug (morphine, codeine, M6G, and M3G; $n=3$ animals per condition) were administered over 5 minutes by using a 26-gauge needle fitted on a $5-\mu l$ Hamilton microsyringe (Hamilton, Bonaduz, Switzerland). After injection, the needle was kept in place for 5 minutes to allow for diffusion of the drugs.

\section{Western blot}

Proteins were separated on sodium dodecyl sulphatepolyacrylamide gel electrophoresis (SDS-PAGE) gradient gels (4-12\% acrylamide; Criterion XT, XT-MOPS running buffer; BioRad, Marnes-la-Coquette, France). Samples $(10 \mu \mathrm{g})$ were suspended in $20 \mu \mathrm{l}$ of loading buffer $(2 \%$ SDS, 4 M urea, 5\% glycerol, 5 mM EDTA, 1\% $\beta$-mercaptoethanol, $60 \mathrm{mM}$ Tris-HCl, $\mathrm{pH}$ 6.8) and boiled for 10 minutes prior to gel loading. After migration, proteins were electrotransferred onto polyvinyldifluorene membrane (GE Healthcare Bioscience) (Goumon et al., 2006). After 30 minutes of saturation (PBS supplemented with $3 \%$ BSA and $0.05 \%$ Tween 20), the 6D6 antibody was used at a dilution of 1:3,000 (in PBS supplemented with $3 \%$ BSA and $0.05 \%$ Tween 20). Immunoreactivity was revealed by using an HRP-conjugated donkey anti-mouse antiserum (P.A.R.I.S.; 1:50,000 in the same buffer) and a Supersignal West Femto Kit (Pierce, Rockford, IL). Nonspecific binding of the secondary antibody was tested by omitting the 6D6 antibody; it showed no nonspecific labeling.

Commercial morphine-BSA $(0.1 \mu \mathrm{g}$; \#80-IM50, Fitzgerald Industries International) was used to determine whether the anti-morphine 6D6 antibody (Aviva Systems Biology) recognized morphine-protein complexes on a Western blot.

\section{Photomicrographs}

Figures including photomicrographs were made with Adobe Photoshop software without changing brightness, contrast, and exposure. For all series of experiments using microscopy, images were captured with the same parameters and settings of brightness, contrast, and exposition.

\section{RESULTS}

\section{Characterization of morphine and morphine glucuronides in the mouse brain by mass spectrometry}

In order to confirm the presence of morphine and morphine-derived compounds in mouse brain extracts, LC-MSMS analysis was performed in SRM mode. The specific transition $\mathrm{m} / \mathrm{z} 286.1 \rightarrow 201.1$ and $\mathrm{m} / \mathrm{z} 286.1 \rightarrow 165.1$ was used to qualify the presence of morphine, $\mathrm{m} / \mathrm{z} 462.1 \rightarrow$ $\mathrm{m} / \mathrm{z} 286.1$ and $\mathrm{m} / \mathrm{z} 201.1$ for M6G and M3G, and $\mathrm{m} / \mathrm{z}$ $300.2 \rightarrow \mathrm{m} / \mathrm{z} 225, \mathrm{~m} / \mathrm{z} 214.8, \mathrm{~m} / \mathrm{z}$ 199.0, m/z 164.8, and $\mathrm{m} / \mathrm{z} 123.0$ for codeine. After comparison with the MS performed on morphine, M6G, M3G, and codeine standards (Fig. 1A), analysis of the whole mouse brain extract allowed for detection of morphine and codeine and, for the first time, detection of endogenous M6G and M3G (Fig. 1B). Endogenous morphine, codeine, M6G, and M3G levels were (per gram of wet brain; $\mathrm{n}=3$ ) $1.01 \pm 0.31 \mathrm{pmol} / \mathrm{g}, 0.61 \pm$ $0.22 \mathrm{pmol} / \mathrm{g}, 0.25 \pm 0.15 \mathrm{pmol} / \mathrm{g}$, and $0.21 \pm 0.22$ $\mathrm{pmol} / \mathrm{g}$, respectively.

In order to rule out a hypothetical intake of exogenous alkaloids from mouse diet, the same extraction protocol used to extract endogenous alkaloids from mouse brain was performed on $2 \mathrm{~g}$ of mouse food pellet. MS analysis performed on the food extract was unable to detect morphine, codeine, M6G, or M3G (data not shown), indicating that endogenous alkaloids do not result from exogenous compounds present in the diet.

\section{Antibody selectivity}

The specificity of the mouse monoclonal 6D6 anti-morphine antibody was investigated by several means.

\section{D6 anti-morphine antibody cross-reactivity with morphine, morphine derivatives, and monoamines}

The cross-reactivity of the 6D6 antibody with morphine, M6G, M3G, and endogenous morphine precursors (codeine, THP, dopamine, L-DOPA, and DOPAC) as well as epinephrine and norepinephrine was tested by ELISA (Fig. 2). The 6D6 antibody displayed an affinity for morphine ( $\mathrm{K}=$ $20.93 \mathrm{nM}), \mathrm{M} 6 \mathrm{G}(\mathrm{K}=8.1 \mathrm{nM}), \mathrm{M} 3 \mathrm{G}(\mathrm{K}=7.56 \mathrm{nM})$, and codeine $(\mathrm{K}=18.15 \mathrm{nM})$. No cross-reactivity was found for the other monoamines tested (Fig. 2). These data confirm that the 6D6 antibody can simultaneously detect morphine, codeine, M6G, and M3G in brain structures without interfering with the other components tested above.

\section{The 6D6 anti-morphine antibody is able to detect morphine-linked protein following PFA treatment}

The efficiency of the cross-linking of alkaloids to proteins after PFA treatment is a matter of debate. PFA may 


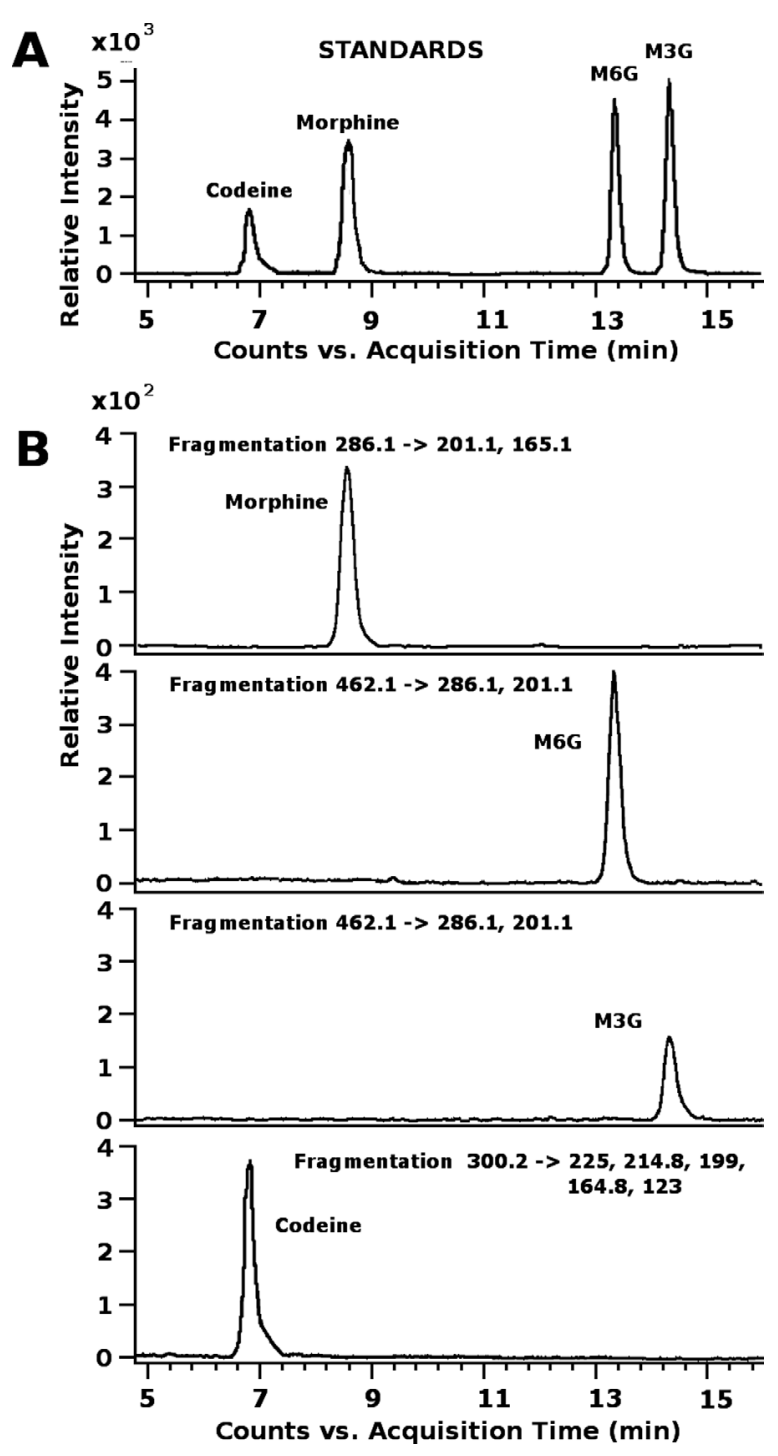

Figure 1. LC-MS-MS analysis of morphine, M6G, M3G, and codeine presence in mouse brain. A: Relative intensity of the MS-MS ions observed for morphine, M6G, M3G, and codeine standards. B: Relative intensity of the MS-MS ions specific for morphine, M6G, M3G, and codeine present in mouse brain extracts.

react with primary and secondary amines. For instance, formaldehyde has been described to react with aliphatic or aromatic amine (Walker, 1964; Kunkel et al., 1981) and alkaloids, in general, are expected to form complexes with formaldehyde (Hesse, 2002).

To determine whether morphine and its related compound can be cross-linked to proteins (i.e., covalent morphine-protein complexes) following PFA treatment, we first examined whether the anti-morphine 6D6 was able to detect commercial morphine-BSA complexes on a Western blot. BSA $(0.1 \mu \mathrm{g})$ and commercial morphineBSA $(0.1 \mu \mathrm{g})$ were loaded onto an SDS-PAGE gel, and the anti-morphine 6D6 was used to detect morphine-like immunoreactivity after gel blotting (Fig. 3A). Immunodetec- tion allowed us to detect a band around $66 \mathrm{kDa}(\mathrm{n}=5$; BSA, $67 \mathrm{kDa}$ ) corresponding to morphine-BSA. Immunoreactive bands were also observed for higher molecular weights and correspond to multimers of morphine-BSA resulting from the action of the coupling agent on BSA. This control indicated that morphine, covalently linked to a protein, can be detected by Western blot with the antimorphine 6D6 antibody. Complementary experiments omitting the anti-morphine 6D6 antibody confirmed that the label was not due to cross-reactivity of the secondary antibody with BSA or morphine-BSA (Fig. 3A).

We performed PFA fixation on commercial BSA to determine whether exogenous alkaloids can be crosslinked to this reference protein. Thus, codeine, M3G, M6G, or morphine was incubated with BSA in the presence or absence of PFA. Samples corresponding to $10 \mu \mathrm{g}$ of BSA were loaded on an SDS-PAGE gel. After migration and electroblotting, immunodetection was performed by using the anti-morphine 6D6 antibody. A diffuse immunolabeling due to alkaloid cross-linking and BSA-polymer cross-linking was observed for BSA treated with PFA in the presence of codeine, M3G, M6G, or morphine (Fig. $3 B)$. No immunoreactivity was observed for the controls (BSA alone, BSA incubated in the presence of the alkaloids without PFA, and BSA alone treated with PFA). This experiment clearly demonstrates that PFA is able to induce cross-linking of codeine, M3G, M6G, or morphine to a protein. The experiment using BSA treated with PFA ruled out possible cross-immunoreactivity of the secondary antibody that may be due to PFA treatment (Fig. 3A).

In addition, total mouse brain extracts (containing endogenous alkaloids) treated or not treated with PFA in vitro were assayed by Western blot. A diffuse immunoreactive label was observed for PFA-treated extracts (around $80-90 \mathrm{kDa}, \mathrm{n}=5$ ), which is likely due to a crosslink between many different proteins and endogenous alkaloids. Control experiments showed no immunolabel for non-fixed brain extracts and for the control experiment using the secondary antibody alone (Fig. 3C). These results show that endogenous morphine-like compounds are fixed to proteins only after PFA treatment. An identical result was obtained with brain tissue from mice perfused with PFA (in vivo; data not shown).

Additional experiments were done after codeine, M3G, M6G, or morphine intracerebroventricular injections (i.c.v.; $20 \mathrm{nmol} ; \mathrm{n}=3$ ) in mice. Mice were perfused with PFA 30 minutes (morphine, codeine) or 1 hour (M3G/ M6G) after i.c.v. injections. These times are necessary to obtain a high concentration of exogenous alkaloids in the brain (Okura et al., 2003). The resulting brain slices underwent immunohistochemistry experiments using the anti-morphine 6D6 antibody. The tissues from each injection condition were processed simultaneously, using the 
same batches of reagents and the same development times. As a result, and for example, 6D6 immunoreactivity in cells, extracellular space, and processes was stronger after alkaloid injections in the striatum in comparison

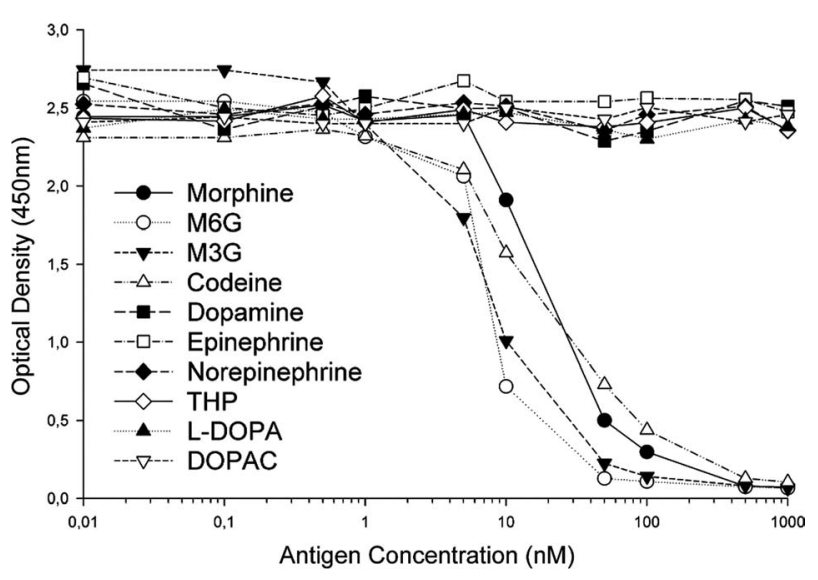

Figure 2. Competitive immunoenzymatic determination (ELISA) of 6D6 morphine antibody specificity for morphine, M6G, M3G, codeine, dopamine, L-DOPA, DOPAC, norepinephrine, epinephrine, and THP. The antibody is blocked with specific antigens when the optical densities decrease. The 6D6 morphine antibody is able to recognize morphine, codeine, M3G, and M6G. DOPAC, dihydroxyphenylacetic acid; L-DOPA, L-3,4-dihydroxyphenylalanine; M3G, morphine-3-glucuronide; M6G, morphine-6-glucuronide; THP, tetrahydropapaveroline. with saline-injected mice (data not shown). For alkaloidinjected mice, MIR density gradients in cells, extracellular space, and processes were dependent on the distance from the injection site (LV, lateral ventricle; data not shown). These results are consistent with those of previous studies showing that exogenous morphine can be stored in cells containing endogenous morphine (Bianchi et al., 1993).

Control experiments using MS analysis, performed after i.c.v. administration of $20 \mathrm{nmol}$ of exogenous morphine, allowed us to determine that the morphine concentration increased to $16 \pm 3.5 \mathrm{nmol}$ per brain $(n=4)$.

These results indicate that morphine, M6G, M3G, and codeine are properly fixed by PFA in mouse brain and that the $6 \mathrm{D} 6$ antibody is able to detect them in situ.

\section{Distribution of endogenous morphine-like immunoreactivity in the adult mouse brain Immunohistochemistry}

Light microscopy was used to analyze morphine, morphine glucuronides, and codeine immunoreactivity (MIR) present in the adult mouse brain by using the 6D6 antibody.

Analysis of the MIR present in the olfactory structures, cortex, basal forebrain and ganglia, hippocampus, thalamus, hypothalamus, subthalamus, midbrain, cerebellum,
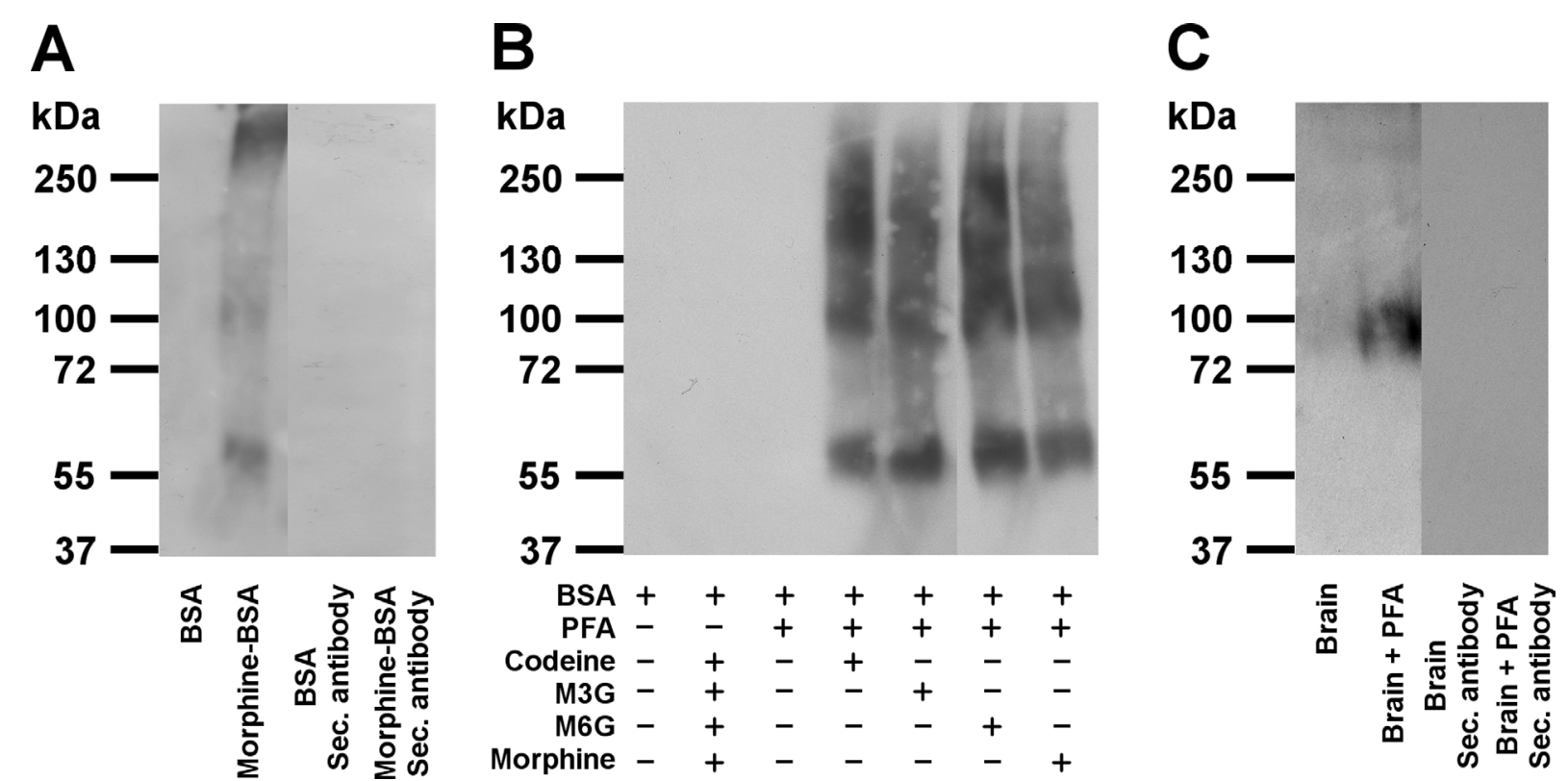

Figure 3. Controls for cross-linking of alkaloids to proteins after paraformaldehyde (PFA) treatment using a Western blot approach. A: Validation of the 6D6 antibody use for Western blot analysis (1:4,000). 6D6 antibody immunolabel observed for bovine serum albumin (BSA) alone (control) and morphine-BSA $(0.5 \mu \mathrm{g} ; 67 \mathrm{kDa} ; \mathrm{n}=5)$. The two last lanes correspond to the control (BSA and morphine-BSA) using the secondary antibody alone. B: Cross-linking experiments of alkaloids to BSA with or without PFA treatments. Immunolabel is only observed for alkaloids after PFA treatment. C: Immunolabel of morphine-like compounds linked to total mouse brain proteins (10 $\mu \mathrm{g}$ ) before and after PFA treatment. A diffuse immunolabel at 80-90 kDa can only be observed after PFA treatment. The two last lanes correspond to the control using the secondary antibody alone (unfixed and fixed brain proteins). 
pons, and medulla was performed on the adult mouse brain and is summarized in Table 2.

\section{Olfactory structures}

In the olfactory system, MIR was observed in the primary and secondary olfactory structures. Strong immunolabeling was detected in the glomerular layer and the external plexiform layer of the olfactory bulb, both in cell bodies and in cell processes (Fig. 4A). In the mitral cell layer, mitral cells were not labeled, but strong labeling was present in the granule cells of the $\gamma$-aminobutyric acid (GABA)ergic granular cell layer (Fig. 4B). In addition, MIR was also found in cells and processes in the core of the olfactory bulb and peduncle corresponding to the

TABLE 2.

Distribution of Morphine-Like Immunoreactivity in the Adult Mouse Central Nervous System ${ }^{1}$

\begin{tabular}{|c|c|c|c|c|c|}
\hline Structure & Cell bodies & Processes & Structure & Cell bodies & Processes \\
\hline Olfactory bulb & & & Subthalamus & & \\
\hline Granular cell layer & + & + & Zona incerta & ++ & ++ \\
\hline Mitral cell layer & - & ++ & Subthalamic nucleus & + & ++ \\
\hline External plexiform layer & - & ++ & Midbrain & & \\
\hline Glomerular layer & + & +++ & Substantia nigra compact part & - & ++ \\
\hline Olfactory system & & & Substantia nigra reticular part & + & ++ \\
\hline Piriform cortex & - & ++ & Ventral tegmental area & - & ++ \\
\hline Anterior olfactory nu. & + & + & Red nucleus & +++ & ++ \\
\hline Endopiriform nucleus & - & ++ & Interpeduncular nucleus & - & + \\
\hline Tenia tecta & + & ++ & Periaqueductal gray & - & +++ \\
\hline Olfactory tubercle & ++ & + & Oculomoteur nucleus (III) & - & +++ \\
\hline Basal forebrain & & & Dorsal raphe nucleus & - & +++ \\
\hline Septohippocampal nucleus & + & ++ & Median raphe nucleus & - & +++ \\
\hline Lateral septal nucleus & - & ++ & Superior colliculus & + & ++ \\
\hline Medial septal nucleus & + & ++ & Inferior colluculus & +++ & ++ \\
\hline Triangular septal nucleus & ++ & ++ & Midbrain reticular nucleus & - & ++ \\
\hline Diagonal band of Broca & ++ & ++ & Nucleus of the optic tract & + & + \\
\hline Bed nucleus of the stria terminalis & - & ++ & Nucleus of Darkschewitsch & ++ & ++ \\
\hline Substantia innominata & +++ & ++ & Interstitial nucleus of Cajal & ++ & ++ \\
\hline Basal ganglia & & & Anterior tegmental nucleus & + & ++ \\
\hline Accumbens nucleus & +++ & ++ & Ventral tegmental nucleus & ++ & ++ \\
\hline Caudate putamen & +++ & ++ & Cerebellum & & \\
\hline Fundus striati & - & + & Cerebellar cortex & & \\
\hline Globus pallidus & + & +++ & Granular layer & + & + \\
\hline Amygdala & & & Purkinje layer & ++ & ++ \\
\hline Posterior amygdala nucleus & + & ++ & Molecular layer & - & +++ \\
\hline Basolateral/lateral amygdala nucleus & - & + & Deep cerebellar nucleus & ++ & ++ \\
\hline Medial amygdala nucleus & - & ++ & Pons & & \\
\hline Hippocampal formation & & & Periolivary nucleus & ++ & + \\
\hline Subiculum & ++ & ++ & Nucleus of the trapezoïd body & + & ++ \\
\hline Ammon's horn & + & ++ & Principal sensory trigeminal nu. & - & ++ \\
\hline Dentate gyrus & & & Central gray of pons & - & + \\
\hline Polymorph layer & + & +++ & Nucleus of the lateral lemniscus & ++ & ++ \\
\hline Subgranular zone & +++ & ++ & Parabrachial nucleus & - & + \\
\hline Granular layer & - & + & Pontine reticular nucleus & - & ++ \\
\hline Molecular layer & + & ++ & Reticulotegmental nu. of pons & - & ++ \\
\hline Thalamus & & & Pontine raphe nucleus & - & ++ \\
\hline Anteroventral thalamic nucleus & - & ++ & Medulla & & \\
\hline Paraventricular thalamic nucleus & - & +++ & Prepositus nujcleus & - & ++ \\
\hline Medial habenular nucleus & - & ++ & Vestibular nucleus & ++ & +++ \\
\hline Reticular thalamic nucleus & - & +++ & Spinal trigeminal nucleus & - & ++ \\
\hline Ventromedial thalamic nucleus & - & ++ & Gigantocellular reticular nucleus & - & + \\
\hline Subparafascicular thalamic nucleus & - & ++ & Area postrema & - & ++ \\
\hline Lateral geniculate nucleus & + & +++ & Medullary reticular nucleus & - & ++ \\
\hline Hypothalamus & & & Gracile nucleus & - & ++ \\
\hline Paraventricular hypothalamic nucleus & - & ++ & Raphe magnus nucleus & - & ++ \\
\hline Lateral preoptic area & - & ++ & External cuneate nucleus & - & ++ \\
\hline Magnocellular preoptic nucleus & - & + & Dorsal cochlear nucleus & ++ & + \\
\hline
\end{tabular}

${ }^{1}$ The intensity of immunolabeling was qualitatively determined by using the caudate putamen $(+++)$ and the granular layer of the hippocampal formation $(-)$ as references. Intensity of morphine-like immunoreactivity ranges from no signal $(-)$ to high signal $(+++)$ and refers to both labeling intensity and the number of labeled elements. Only positive structures are shown. 

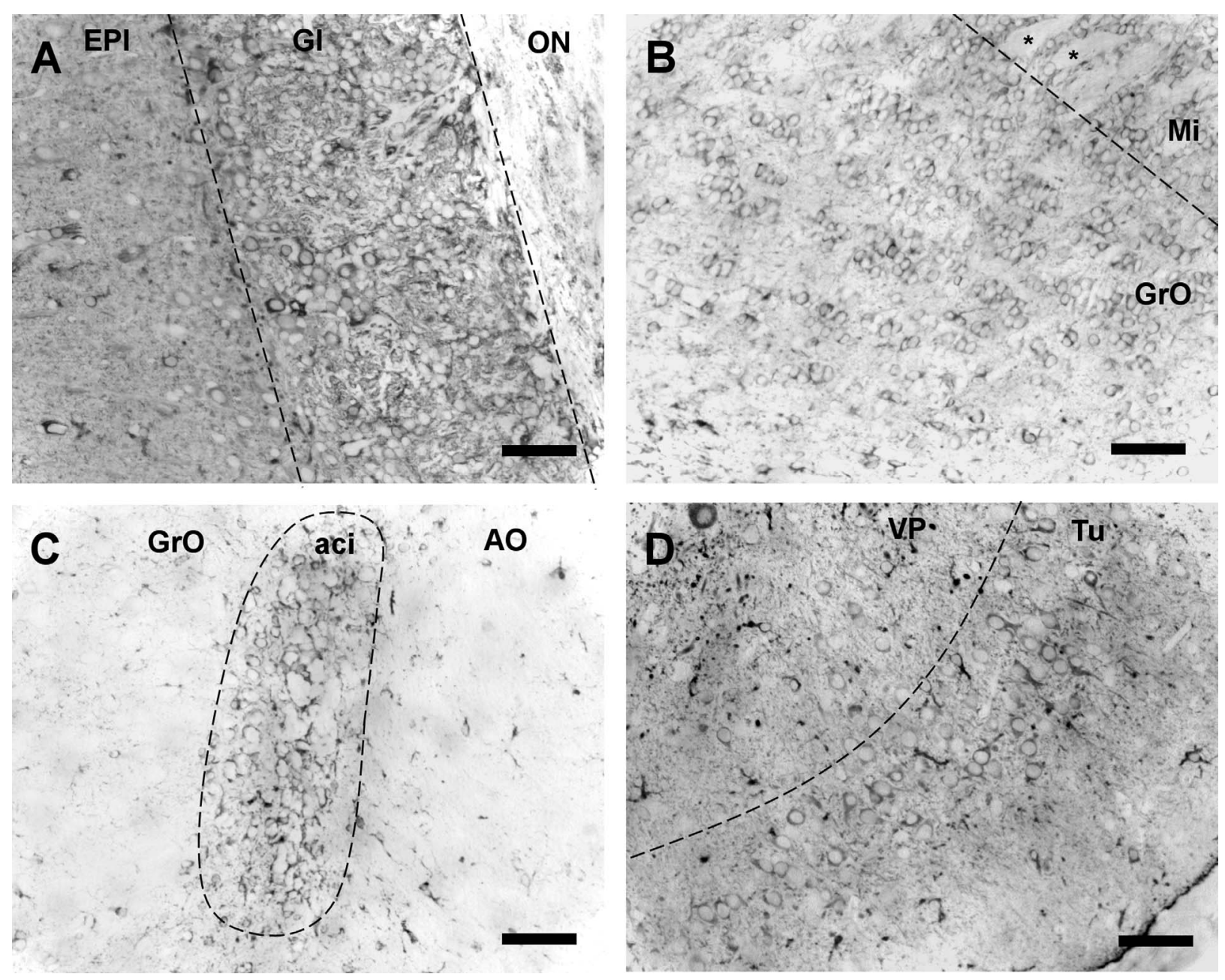

Figure 4. Distribution of MIR detected in the olfactory structures of the adult mouse brain. A: MIR observed in neurons and astrocytes of the glomerular layer of the olfactory bulb. B: MIR is present in the granule cells of the granular cell layer of the olfactory bulb, but no label is observed in the mitral cells (asterisk). C: MIR present in the soma and processes of astrocytes from the anterior commissure intrabulbar. D: MIR in neurons and astrocytes (darker cells) of the olfactory tubercle. aci, anterior commissure, intrabulbar part; AO, anterior olfactory nucleus; EPI, external plexiform layer; GI, glomerular layer; GrO, granular cell layer; Mi, Mitral cell layer; ON, olfactory nerve layer; Tu, olfactory tubercle; VP, ventral pallidum. Scale bar $=50 \mu \mathrm{m}$ in A-D.

anterior intrabulbar commissure (Fig. 4C). In the secondary olfactory structures, MIR was found both in neurons and in astrocytes of the olfactory tubercle (Fig. 4D). The labeling of the piriform cortex was the same as that of the other parts of the cortex (see below).

\section{Cortex}

Morphine-like immunoreactivity was found to be moderate throughout the cerebral cortex. Immunoreactivity was distributed across the entire thickness of the cortex (Fig. 5A). No strict correlation was detected between the distribution of MIR and functional cortical regions. Whereas MIR was relatively uniform and similar in both motor and sensory areas, stronger MIR was present in the cingulate area of the cortex. Higher magnification suggested the MIR was localized in different subsets of cells including neurons (Fig. 5B, black arrow), astrocytes (Fig. 5B, white arrow), and astrocytic feet (Fig. 5C, arrow). In the molecular layer of the cortex, dense labeling was found in processes. Electron microscopy allows us to identify astrocytic processes (Fig. 5D, white arrow) and postsynaptic neuronal endings, recognizable by the typical postsynaptic density (Fig. 5D,E, black arrow).

\section{Basal forebrain, basal ganglia, and amygdala}

In the basal forebrain, MIR was observed in neuronal cells of the septal structures, the septohippocampal nucleus, the medial septal nucleus, and the triangular nucleus of the septum (Fig. 6A). Similar immunolabeling was observed in neurons of the substantia 

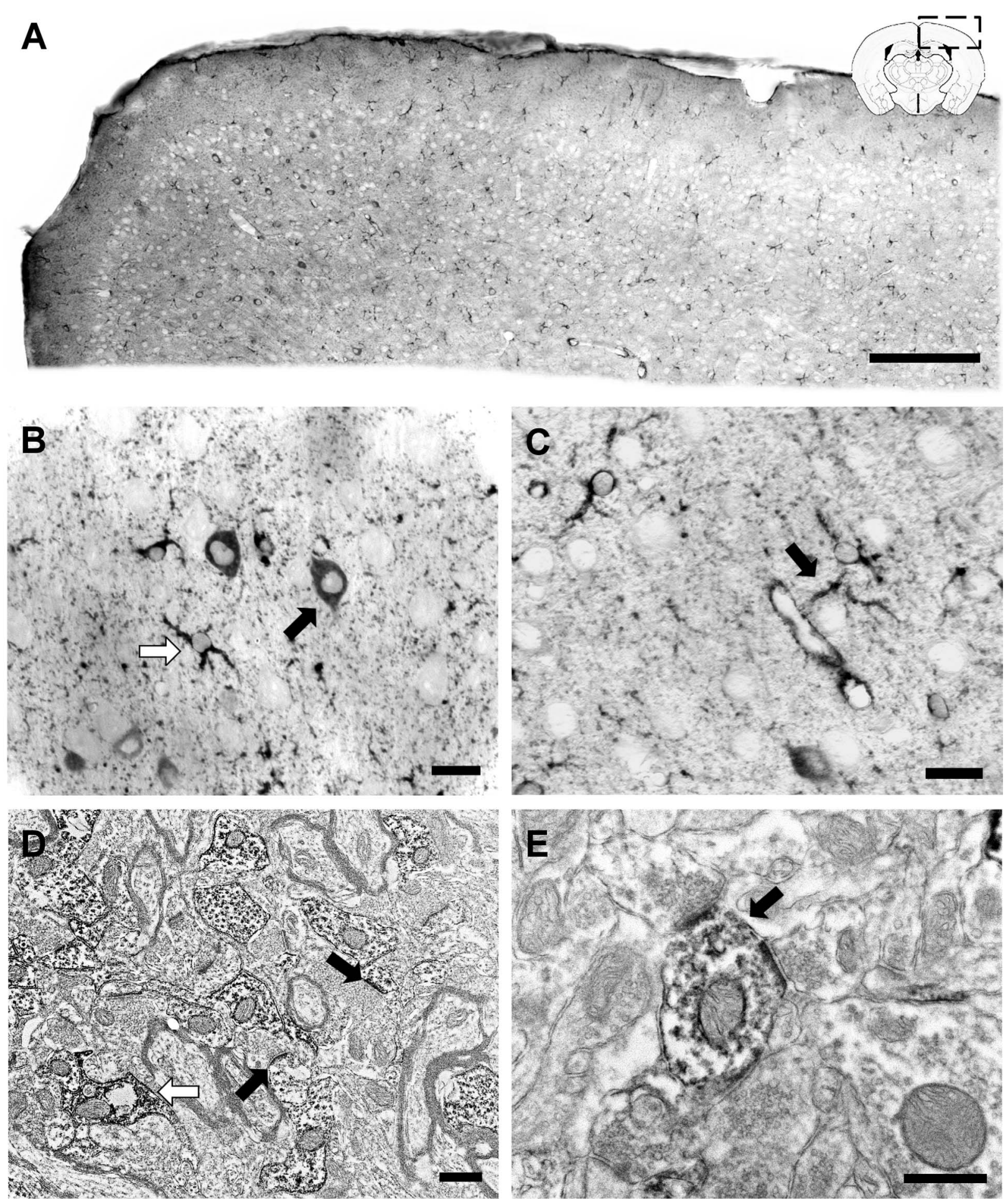

Figure 5. Distribution of MIR present in the cortex of the adult mouse brain. A: MIR observed in neurons and astrocytes from the left cortex (coronal slice). B: MIR in neurons (black arrow) and astrocytes (white arrow) of the cortex. The white round shapes correspond to unlabeled neurons. C: MIR present in an astrocytic foot around a blood vessel in the cortex (arrow). D,E: Electron microscopy of the molecular layer of the cortex showing labeled dendrites including some postsynaptic endings recognizable by their postsynaptic density (black arrows in $\mathrm{D}, \mathrm{E}$ ) and astrocytic process (white arrow, in D), which have a darker staining. Scale bar $=200 \mu \mathrm{m}$ in A; $20 \mu \mathrm{m}$ in B,C; $500 \mathrm{~nm}$ in D,E.

innominata (Fig. 6B) and in the diagonal band of Broca (Fig. 6C).
In the basal ganglia, MIR was observed in numerous cells and processes. In the striatum, intense MIR was found in small cells uniformly distributed among the 

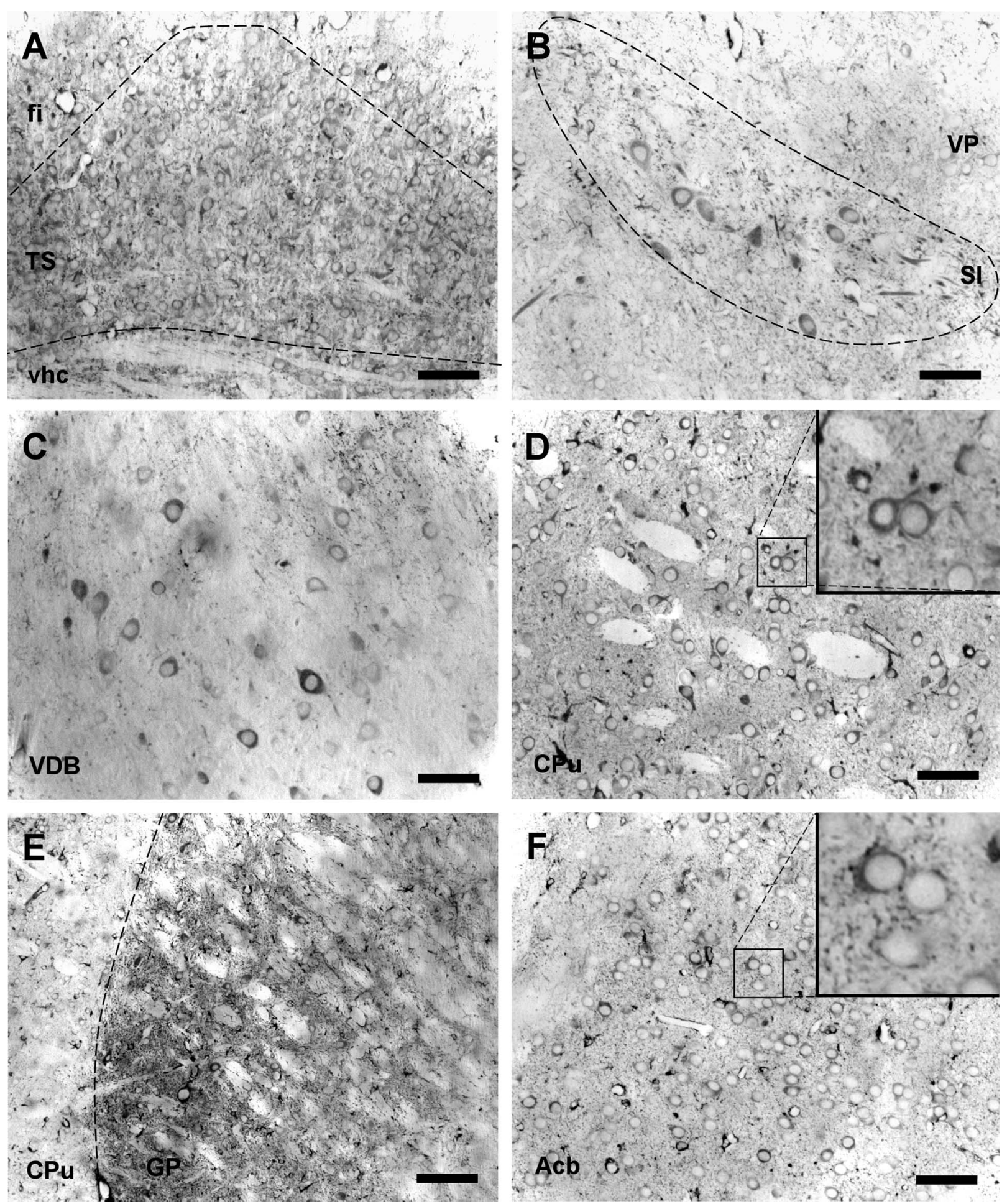

Figure 6. Distribution of MIR in the basal forebrain and basal ganglia of the adult mouse brain. A: MIR present in neurons and astrocytes in the triangular septal nucleus. B: MIR neurons of the substantia innominata. C: MIR in neurons of the nucleus of the vertical limb of the diagonal band of Broca. D: Dense MIR observed in neurons of the caudate putamen but also in astrocytes. The frame on the upper right corner displays a higher magnification of two neurons. E: MIR present in neurons and astrocytes of the globus pallidus. F: MIR in the neurons of the nucleus accumbens. The frame on the upper right corner displays a higher magnification of two neurons. Acb, accumbens nucleus; $\mathrm{CPu}$, caudate putamen; fi, fimbria of the hippocampus; GP, globus pallidus; SI, substantia innominata; TS, triangular septal nucleus; $\mathrm{VDB}$, nucleus of the vertical limb of the diagonal band of Broca; vhc, ventral hippocampal commissure; VP, ventral pallidum. Scale bar $=$ $50 \mu \mathrm{m}$ in A-D,F; $100 \mu \mathrm{m}$ in $\mathrm{E}$. 
dorsal and ventral parts of this structure (Fig. 6D). In the globus pallidus, labeling was observed in some isolated cells as well as in processes and terminals (Fig. 6E). Throughout the nucleus accumbens, MIR distribution and intensity were similar to those observed in the striatum (Fig. 6F).

MIR in the amygdala was weak. Only the posterior amygdala nucleus contained some isolated MIR neurons. The basolateral, lateral, and medial amygdalar nuclei contained MIR only in some processes and terminals (data not shown).

\section{Hippocampal formation}

MIR was distributed in all hippocampal structures. In the lateral and central blade of the dentate gyrus, MIR was found not only in cells of the subgranular zone (SGZ), but also in some isolated cells present in the granular layer and in the polymorphic layer. No granule cells appeared to be labeled (Fig. 7A,B). In the SGZ, labeling was present in two morphologically different types of cells (Fig. 7B). Electron microscopy enabled detection of MIR in the basket cells of the SGZ (Fig. 7D) and in radial astrocytes (Fig. 7E) (von Bohlen Und Halbach, 2007). MIR was also observed in horizontal astrocytes of the SGZ. In Ammon's horn, MIR was homogeneously distributed. Labeled cells, processes, and astrocytic feet around blood vessels were observed in these layers (Fig. 7C).

\section{Thalamus}

In the thalamus, only the lateral geniculate nucleus (dorsal and ventral part) showed MIR in some cells displaying a neuronal morphology (Fig. 8A). MIR was also observed in processes and astrocyte-like cells distributed throughout the entire thalamus. In some structures (see Table 2), the density of processes appeared to be more prominent (i.e., anteroventral thalamic nucleus, reticular thalamic nucleus, and paraventricular thalamic nucleus; Fig. 8B-D).

\section{Hypothalamus and subthalamus}

Most of the hypothalamic structures displayed low levels of MIR. However, in the subthalamus, labeling of neuronal cells was observed in the zona incerta (Fig. 8E) and in the subthalamic nucleus (Fig. 8E,F). Only low levels of MIR were observed in other nuclei.

\section{Midbrain}

Low to high levels of MIR were present in midbrain areas. MIR was not observed in the neurons of the main dopaminergic nuclei of the midbrain; it was only observed in processes (in the substantia nigra pars compacta and ventral tegmental area). Only a few isolated neurons were labeled in the reticular part of the substantia nigra (Fig. 9A). In contrast, in the tectal areas, many strongly immunopositive neurons were present in the inferior colliculus (Fig. 9B), whereas only some isolated neurons were stained in the superior colliculus. In the tegmental areas, the ventral tegmental nucleus (Fig. 9C) and the anterior tegmental nucleus contained MIR-positive neurons. MIR was also present in neurons of the nucleus of Darkschewitsch (Fig. 9D), the red nucleus, and the interstitial nucleus of Cajal. In other midbrain structures, MIR was found in endings and processes (see Table 2). For example, dense processes were observed in the whole periaqueductal gray (PAG; Fig. 9E).

\section{Cerebellum}

As previously published (Muller et al., 2008), the MIR was distributed in all structures of the cerebellar cortex. The labeling intensity was the same in all these areas.

Within the cerebellar cortical structure, MIR present in the Purkinje layer was found in small cells and in processes around the Purkinje cells. Purkinje cells (soma and dendrites) were unlabeled (Fig. 10A). In the granular layer, granule cells displayed weak labeling; nevertheless, some isolated cells displaying a high MIR were found (Fig. 10A, arrow). In the molecular layer, both neuronal and astrocytic processes were labeled. As previously described (Muller et al., 2008), labeling around the Purkinje cell bodies corresponded to the presynaptic terminals of GABAergic basket cells (Fig. 10C, box). Interestingly, we also observed labeling of astrocytic processes all around the Purkinje dendritic tree (Fig. 10D, arrow and box).

In the deep part of the cerebellum, the deep cerebellar nuclei contained MIR in neuronal cells (Fig. 10B)

\section{Pons and medulla}

The pons areas displayed low MIR, with only some nuclei being labeled. MIR present in neuronal cells was observed in the periolivary nucleus and in the nucleus of the trapezoid body (Fig. 11A). Strong labeling was also observed in neurons of the lateral lemniscus complex (dorsal and ventral nuclei; Fig. 11B).

In the medulla, strong MIR was observed in neurons of the dorsal cochlear nucleus (Fig. 11C). In the vestibular nuclei, labeling was present in some cells and was intense in cell processes (Fig. 11D). The raphe magnus nuclei displayed dense processes (Fig. 11E).

\section{Characterization of morphine- immunoreactive cells}

In order to characterize the cells containing morphinelike compounds in the mouse brain, we used a confocal microscopy approach with different cell markers.

\section{Olfactory structures}

In the olfactory structures, cell bodies displaying MIR did not co-localize with the immunoreactivity for two isoforms 

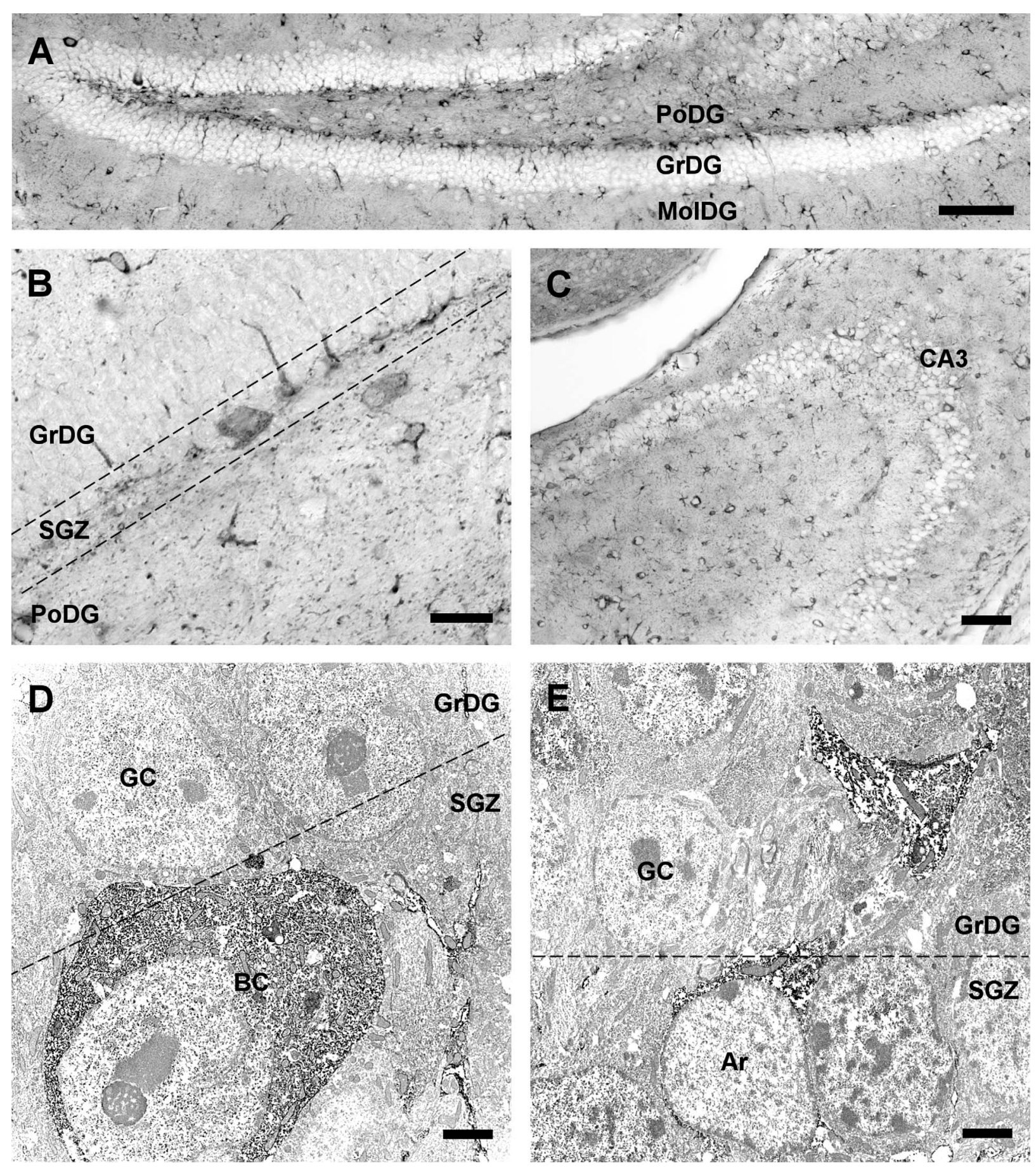

Figure 7. Distribution of MIR in the hippocampal formation of the adult mouse brain. A: MIR in the dentate gyrus; in particular, label is observed in the subgranular zone, whereas no label was detected in the granular layer. B: MIR observed at higher magnification in the dentate gyrus. Neurons and astrocytes are labeled in the subgranular zone. C: MIR present in the CA3 field of Ammon's horn. D,E: Electron microscopy of the subgranular zone showing a MIR-positive basket cell (D) and a radial astrocyte (E) recognizable by the process going through the granular layer. Ar, radial astrocyte; BC, basket cell; CA3, Ammon's horn 3; PoDG, polymorphic layer of the dentate gyrus; GC, granule cell; GrDG, granular layer; MoIDG, molecular layer; SGZ, subgranular zone. Scale bar $=100 \mu \mathrm{m}$ in A,C; $20 \mu \mathrm{m}$ in B; $2 \mu \mathrm{m}$ in D,E.

of the glutamic acid decarboxylase enzyme (GAD65/67) in the glomerular layer, suggesting that GABAergic periglomerular cells do not contain endogenous morphine and/or mor- phine glucuronides. However, in the granule cell layer, colabeling with an anti-GAD65/67 antibody indicated that MIR was present in granule cells (Fig. 12A, arrow). 

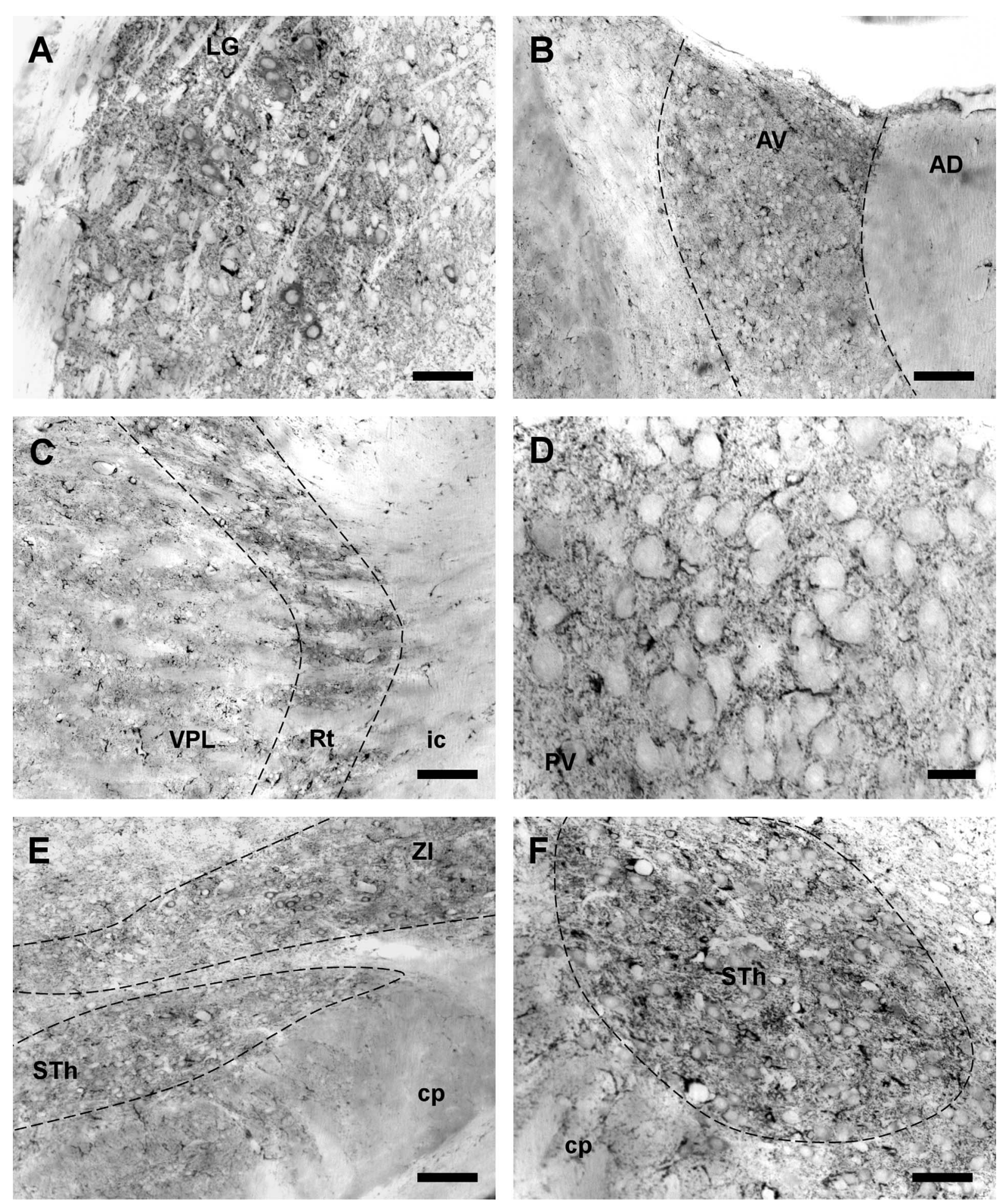

Figure 8. Distribution of MIR in the thalamus, the hypothalamus, and the subthalamus of the adult mouse brain. A: MIR in neurons (round cells) and astrocytes (stellate cells) in the lateral geniculate nucleus. B: MIR present in astrocytes of the anteroventral thalamic nucleus. C: MIR in astrocytes of the reticular thalamic nucleus. D: MIR present in astrocytes and in processes around the soma of the paraventricular thalamic nucleus neurons. E,F: MIR in neurons (round cells) and astrocytes (stellate cells) in the subthalamic nucleus (E,F) and the zona incerta (E). AD, anterodorsal thalamic nucleus; AV, anteroventral thalamic nucleus; $c p$, cerebral peduncle; ic, internal capsule; LG, lateral geniculate nucleus; PV, paraventricular thalamic nucleus; Rt, reticular thalamic nucleus; STh, subthalamic nucleus; VPL, ventral posterolateral thalamic nucleus; ZI, zona incerta. Scale bar $=100 \mu \mathrm{m}$ in B,C,E; $50 \mu \mathrm{m}$ in A,F; $20 \mu \mathrm{m}$ in D. 

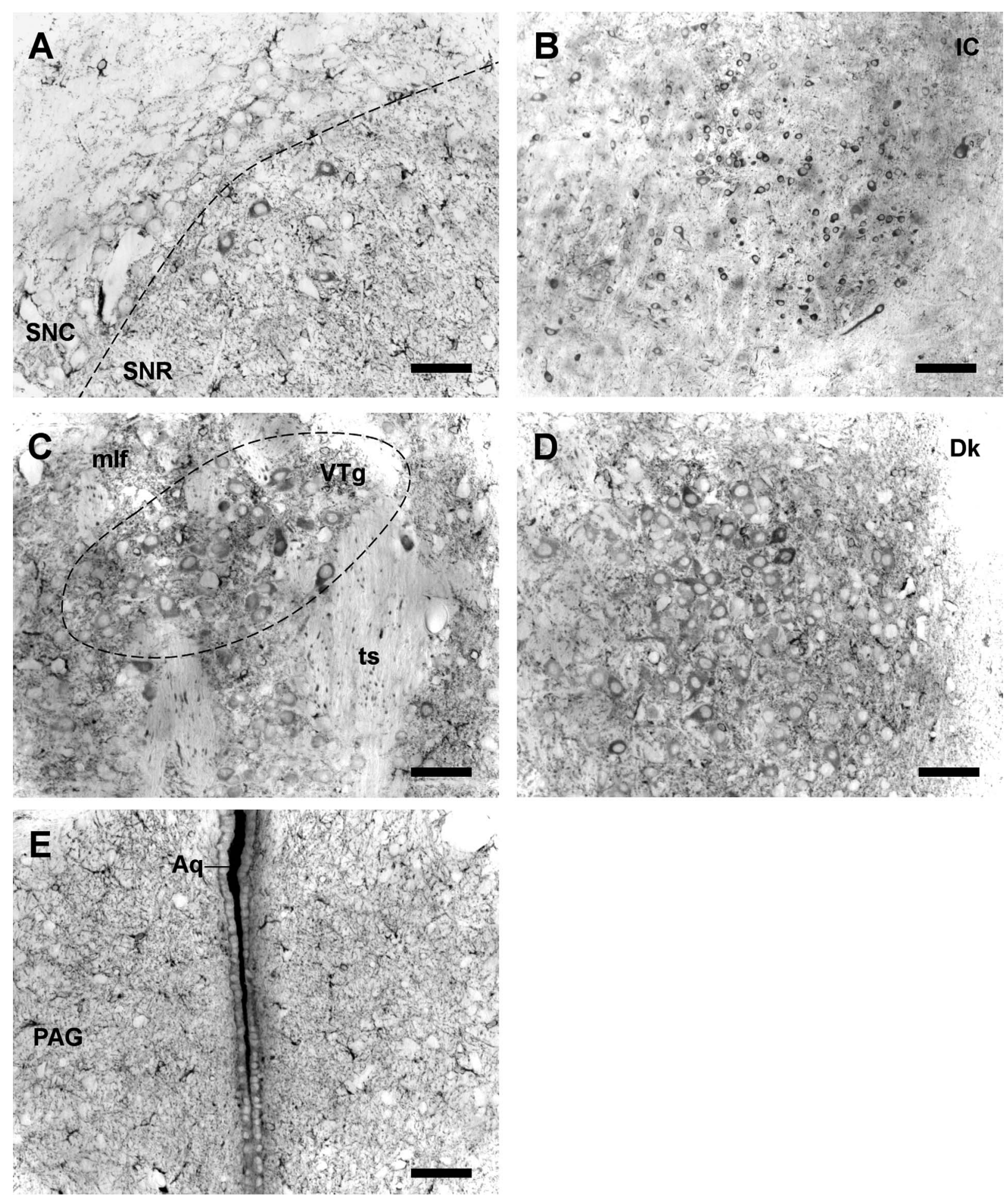

Figure 9. Distribution of MIR in the midbrain of the adult mouse brain. A: MIR in the substantia nigra is present only in neurons of the substantia nigra. B: MIR in neurons of the inferior colliculus. C: MIR observed in neurons of the ventral tegmental nucleus. D: MIR in neurons of the nucleus of Darkschewitsch. E: MIR present in astrocytes and process in the anterior part of the periaqueductal gray. Aq, aqueduct; Dk, nucleus of Dakschewitsch; IC, inferior colliculus; mlf, medial longitudinal fasciculus; PAG, periaqueductal gray; SNC, substantia nigra, compact part; SNR, substantia nigra, reticular part; ts, tectospinal tract; VTg, ventral tegmental nucleus. Scale bar $=100 \mu \mathrm{m}$ in B; $50 \mu \mathrm{m}$ in A,C-E. 

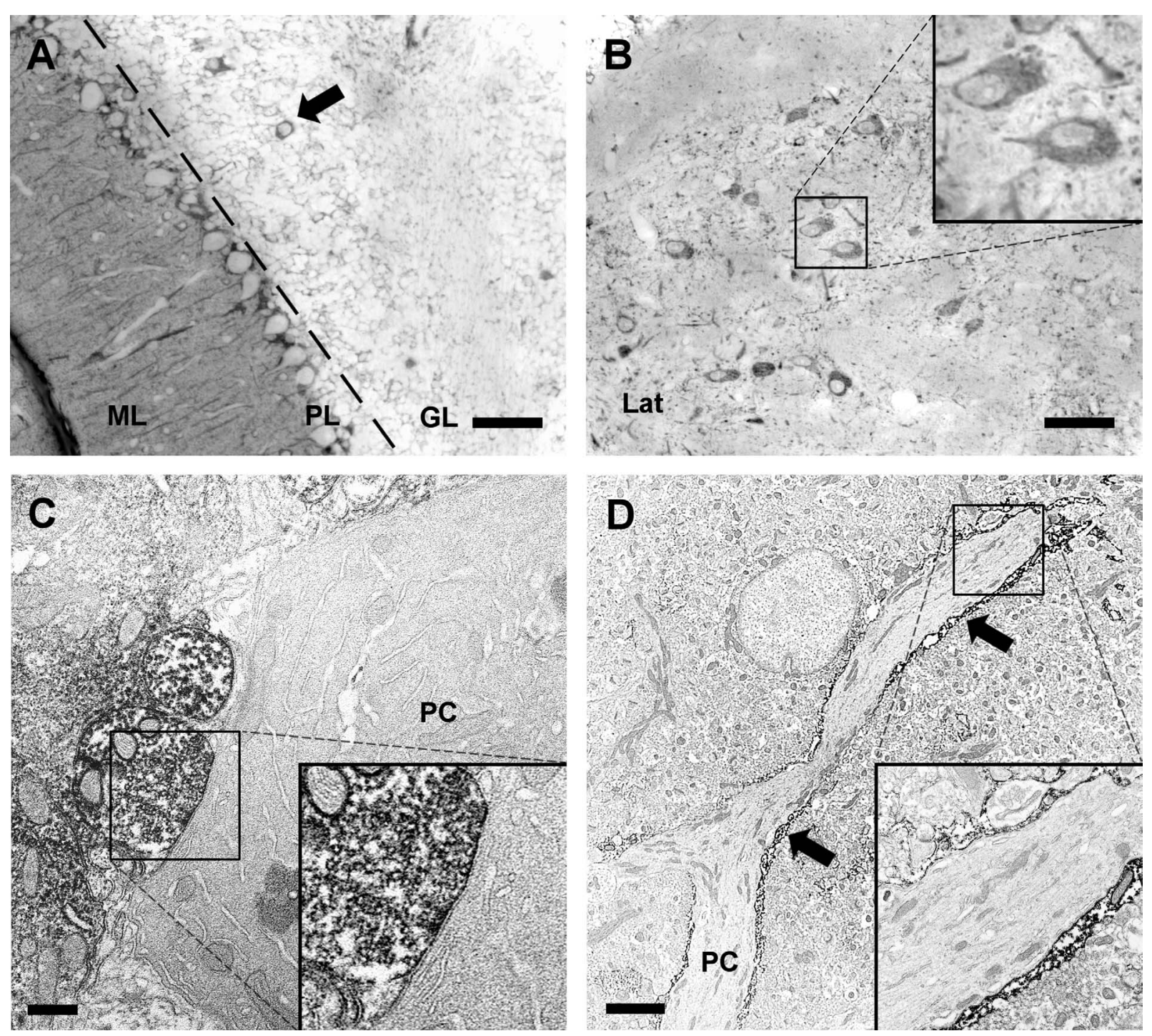

Figure 10. Distribution of MIR in the cerebellum of the adult mouse brain. A: MIR in the cerebellar cortex is present in basket cells of the Purkinje layer, in granule cells, and in astrocytes. The arrow indicates a MIR isolated cell in the granular layer. B: MIR observed in neurons of the lateral cerebellar nucleus. C: Electron microscopy of a labeled presynaptic ending on a Purkinje cell; the panel in the lower right is a higher magnification of the labeled presynaptic element. D: Electron microscopy of labeled astrocytic processes (arrows) around a Purkinje cell dendrite; the panel in the lower right is a higher magnification of the labeled astrocytic processes. GL, granule cell layer; Lat, lateral cerebellar nucleus; ML, molecular layer; PC, Purkinje cell; PL, Purkinje cell layer. Scale bar $=50 \mu \mathrm{m}$ in A,B; $500 \mathrm{~nm}$ in C; $2 \mu \mathrm{m}$ in D.

Double-label immunofluorescence with GFAP antibody revealed that MIR was also present within GFAP-labeled cells, indicating that morphine-like compounds are present in glial cells of the intrabulbar anterior commissure (Fig. 12B).

\section{Cortex}

In cortical structures, both neuronal and astrocyte-like cells were labeled. Immunolocalization of MIR within GAD65/67-positive cells showed that some GABAergic interneurons of the cortex contain MIR (Fig. 12C, arrow). Interestingly, not all GABAergic cells were labeled, sug- gesting that only a specific subpopulation of interneurons contains morphine-like compounds (Fig. 12C). Co-labeling with GFAP showed the presence of MIR in numerous astrocytes in the cortex. Interestingly, MIR was also observed in astrocytic foot processes around blood vessels (Fig. 12D, arrow).

\section{Basal ganglia}

In the striatum, confocal microscopy experiments showed that small, round neuronal cells were immunoreactive for both GAD65/67 and morphine-like compounds (Fig. 12E, arrow), suggesting that medium 

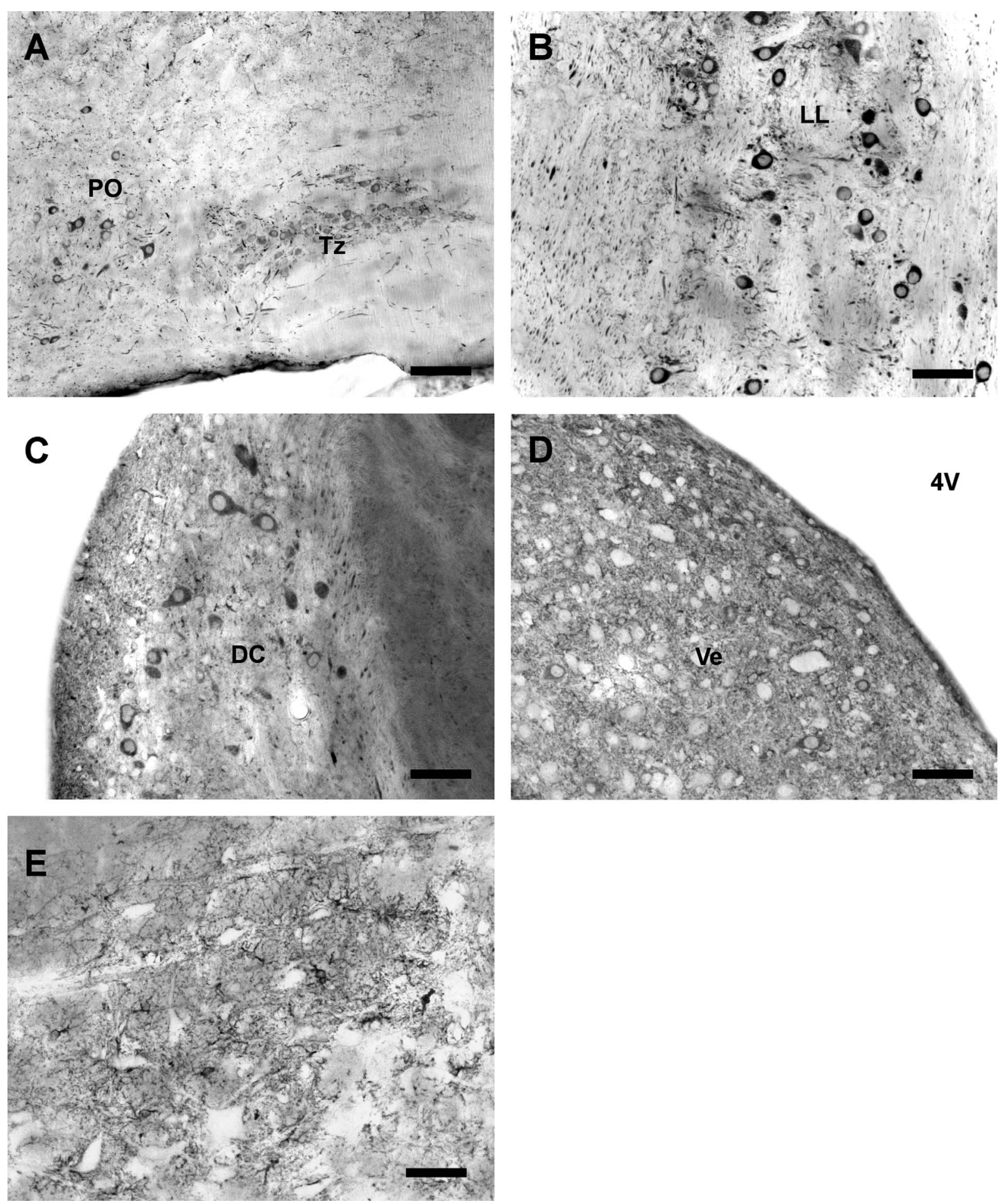

Figure 11. Distribution of MIR in the pons and medulla of the adult mouse brain. A: MIR in neurons of the periolivary nucleus and the nucleus of the trapezoid body. B: MIR observed in the lateral lemniscus. C: MIR present in neurons of the dorsal cochlear nucleus. D: MIR present in neurons and processes of the vestibular nucleus. E: MIR observed in the raphe magnus nuclei is present in astrocytes and processes. 4V, 4th ventricle; DC, dorsal cochlear nucleus; LL, lateral lemniscus; PO, periolivary nucleus; Tz, nucleus of the trapezoid body; Ve, vestibular nucleus. Scale bar $=100 \mu \mathrm{m}$ in $\mathrm{A} ; 50 \mu \mathrm{m}$ in $\mathrm{B}-\mathrm{E}$.

spiny GABAergic interneurons contain morphine and/ or morphine-derived molecules. Interestingly, in the striatum, co-localization of MIR and TH was absent, suggesting that MIR-labeled processes do not correspond to dopaminergic innervation (Fig. 12F). As in the striatum, we found MIR co-localized with GAD65/ 

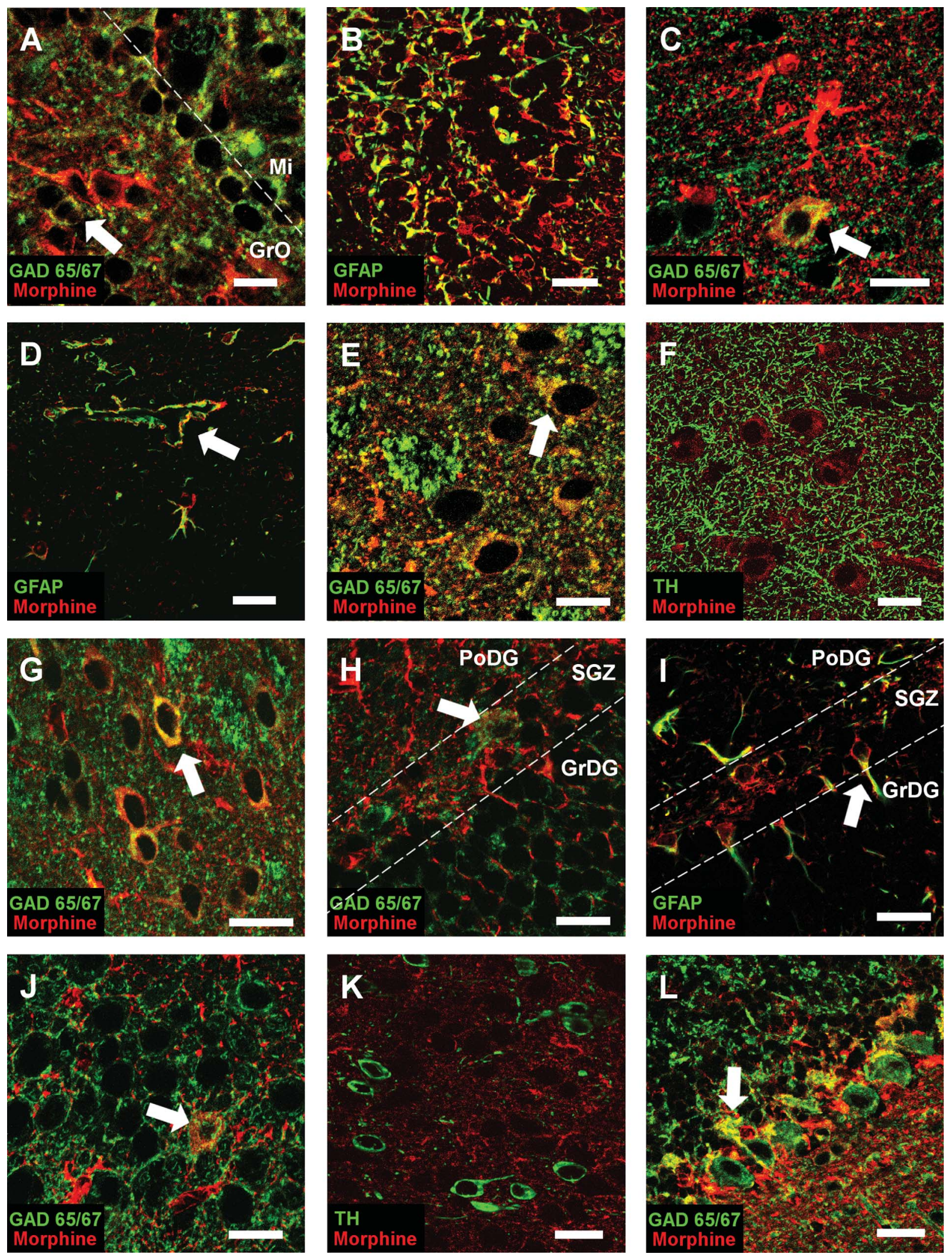

Figure 12 
67 immunoreactivity in small, round cells of the nucleus accumbens, suggesting that GABAergic interneurons of this nucleus contain morphine and/or morphine derivatives (Fig. 12G, arrow).

\section{Hippocampal formation}

Immunofluorescence experiments revealed the presence of two different MIR-positive cell types in the SGZ. First, the co-labeling of cells for MIR and GAD65/67 suggests the presence of endogenous morphine-like compounds in GABAergic cells of the SGZ (Fig. 12H, arrow). Second, co-localization of MIR with GFAP indicated that both radial and horizontal astrocytes of the SGZ were labeled (Fig. 12I); interestingly, the same pattern of labeling was observed in the subventricular zone (data not shown). The MIR astrocytes present in the SGZ displayed a radial phenotype (Fig. 12l, arrow) and may correspond to radial glia-like progenitors (von Bohlen Und Halbach, 2007).

In addition to the SGZ, MIR-positive cells observed in the pyramidal cell layer expressed the GAD65/67 enzyme (Fig. 12J, arrow), indicating that some GABAergic interneurons show MIR in Ammon's horn.

\section{Midbrain}

In the substantia nigra pars compacta, MIR was not found in TH-positive neurons (Fig. 12K).

\section{Cerebellum}

In the Purkinje layer, morphine-like immunoreactivity co-localized with GAD65/67 immunoreactivity, confirming the presence of MIR in basket cells of the Purkinje layer (Fig. 12L, arrow), as previously described (Muller et al., 2008).

\section{DISCUSSION}

The goal of the present study was to determine the localization of endogenous morphine and its derivatives (i.e., morphine, M6G, M3G, and codeine) in mouse brain structures and in specific cell types. These results are similar to those of previously published studies of the localization of endogenous alkaloids in the mouse brain. (Gintzler et al., 1978; Bianchi et al., 1993, 1994; Stefano et al., 2000; Muller et al., 2008). By using classical confocal and electron microscopy, we were able to characterize different structures and cells containing endogenous morphine-like compounds. This article shows the presence of endogenous morphine and/or M6G and/or M3G and/or codeine in both neurons and astrocytes of the mouse brain. Endogenous morphine-like immunoreactivity is usually observed in GABAergic neurons but is absent in dopaminergic neurons. MIR is also found in astrocytes and astrocytic processes throughout the entire brain. The mapping of morphine-like immunoreactivity, presented in this study, is a key step to designing future experiments aimed at better understanding of the role of morphine and/or morphine derivatives in specific brain functions.

\section{Characterization of morphine, codeine, and morphine glucuronides in the mouse central nervous system}

In 1976 Gintzler et al. (1976, 1978) described for the first time the presence of a non-peptide morphine-like compound in the CNS. Since this discovery, many publications have characterized the presence of endogenous morphine and codeine in mammals (Goldstein et al., 1985; Spector et al., 1985; Cardinale et al., 1987; Donnerer et al., 1987; Bianchi et al., 1993; Molina et al., 1995; Muller et al., 2008). In the present paper a mass spectrometry approach

Figure 12. Characterization of MIR-positive cells of the adult mouse brain by confocal microscopy. A: Co-labeling of MIR (red) with GAD65/67 (green) in the periglomerular layer of the olfactory bulb showing the presence of MIR in granule cells. Arrow points to a GABAergic neuron that also expresses MIR. B: Co-labeling of MIR (red) with GFAP (green) in astrocytic processes of the anterior commissure intrabulbar. C: Co-labeling of MIR (red) with GAD65/67 (green) in the cortex showing in red a MIR-positive astrocyte and in yellow (arrow) a GABAergic interneuron that also expresses MIR. D: Co-labeling of MIR (red) with GFAP (green) in the cortex proving the presence of MIR in astrocytes and astrocytic feet around blood vessels (arrow). E: Co-labeling of MIR (red) with GAD65/67 (green) in the caudate putamen. GABAergic cells of the caudate putamen express MIR (arrow). F: Co-labeling of MIR (red) with tyrosine hydroxylase (green) in the caudate putamen. No MIR is observed in dopaminergic endings. G: Co-labeling of MIR (red) with GAD65/67 (green) in the nucleus accumbens. The arrow points to a GABAergic cell of the nucleus accumbens that also expresses MIR (arrow). H: Co-labeling of MIR (red) with GAD65/67 (green) in the subgranular zone of the dentate gyrus proving the presence of MIR in the GABAergic basket cells (arrow). I: Co-labeling of MIR (red) with GFAP (green) in the subgranular zone of the dentate gyrus showing MIR in radial astrocytes (arrow). J: Colabeling of MIR (red) with GAD65/67 (green) in the CA3 field GABAergic cells of Ammon's horn. The arrow points to a GABAergic cell that also expresses MIR in the Ammon's horn. K: Co-labeling of MIR (red) with tyrosine hydroxylase (green) in the substantia nigra pars compacta. No MIR is observed in dopaminergic neurons. L: Co-labeling of MIR (red) with GAD65/67 (green) in the cerebellar cortex. The GABAergic basket cells of the Purkinje layer also express MIR (arrow). GAD, glutamic acid decarboxylase; GFAP, glial fibrillary acidic protein; GrDG, granular layer; GrO, granular cell layer; Mi, mitral cell layer; PoDG, polymorphic layer of the dentate gyrus; SGZ, subgranular zone. Magenta-green images are available as Supplementary Figure 1. Scale bar $=20 \mu \mathrm{m}$ in B-D,F-L; $10 \mu \mathrm{m}$ in A,E. 
allowed us to characterize the presence of endogenous morphine and codeine in mouse brain. In addition, we show here, for the first time, the presence of M3G and M6G in the mouse brain, suggesting that brain UGT enzymes are able to produce these two glucuronides.

\section{MIR and the dopaminergic system}

To our surprise, morphine-like compounds were not found in neurons of dopaminergic areas. Endogenous morphine is thought to derive from dopamine biosynthesis, and its synthesis pathway was characterized in SH-SY5Y, a tumor-derived catecholaminergic cell line (Poeaknapo et al., 2004; Boettcher et al., 2005; Goumon et al., 2009). Moreover, a recent publication showed an absence of endogenous morphine in mice lacking tyrosine hydroxylase, suggesting that dopamine is necessary for endogenous morphine biosynthesis in vivo (Neri et al., 2008). However, several reports suggest that morphinelike compounds can also be synthesized by non-dopaminergic or non-catecholaminergic cells such as pancreatic cells, hepatocytes, and placenta-derived cells (Weitz et al., 1987; Molina et al., 1995; Poeaknapo et al., 2004).

Endogenous morphine-like immunoreactivity was found in non-dopaminergic neurons in the brain. Endogenous morphine-like compounds may derive from an uptake of precursors by the non-dopaminergic neurons. Interestingly, it has been hypothesized that THP, a dopamine metabolite found in extracellular brain spaces, may be used to synthesize morphine-like compounds (Boettcher et al., 2005). To strengthen this idea, a recent report from Zenk's laboratory showed that THP injection in mice leads to morphine production and excretion (Grobe et al., 2010).

Together, these results indicate that, in mouse brain, the biosynthesis of morphine is not completed in dopaminergic neurons and thus strongly suggest that morphinelike compounds present in non-dopaminergic brain cells in vivo may be synthesized after uptake of precursors (e.g., dopamine, THP, or others). Furthermore, this implies cooperation between different cell types to ensure complete endogenous codeine/morphine/glucuronides biosynthesis.

\section{MIR in neurons}

MIR was observed in different neuronal cell bodies, with different neurochemical patterns and different anatomical distributions. MIR was not observed in dopaminergic neurons and processes but was mainly present in GABAergic cells (e.g., in the hippocampus, cortex, and striatum) and also to a lesser extent in glutamatergic neurons (e.g., in deep cerebellar nuclei). There are two possible explanations for the presence of endogenous morphine or related compounds in neurons. One possibility is that endogenous morphine or/and morphine glucuro- nides or/and codeine could be taken up from the extracellular space by active or passive transport. The second is that neurons could take up a morphine precursor (e.g., dopamine, THP, or others) and then produce codeine and/or morphine and/or its derivative. In our study, MIR corresponded to the possible presence of morphine, M6G, M3G, or codeine; it was impossible to determine which of these alkaloids was present in the immunoreactive neurons. However, the presence of UGT1A6 in neurons of the rat brain (Brands et al., 2000) and in neuronal primary cultures (Suleman et al., 1998) suggests that after morphine synthesis or uptake, some neurons are able to synthesize morphine glucuronides.

Our recent studies have focused on the roles of endogenous morphine in the CNS (Muller et al., 2008) and have suggested that endogenous morphine may be cosecreted with other neurotransmitters in the CNS and may be implicated in neurotransmission. Indeed, endogenous alkaloids are localized in large dense-core vesicles in a cell line model (SH-SY5Y) and are secreted by a $\mathrm{Ca}^{2+}$-dependent pathway (Muller et al., 2008). The presence of MIR in the presynaptic terminals of basket cells innervating the Purkinje cells supports this hypothesis. However, although immunoreactivity is present in dendrites and postsynaptic terminals, we were unable to find presynaptic labeling in the rest of the brain. Further investigation will allow us to resolve the mechanism of action of endogenous alkaloids.

\section{MIR in astrocytes}

Our results show the presence of endogenous morphine-like compounds in a large number of astrocytes in all structures of the CNS. Astrocytes do not express tyrosine hydroxylase (Jaeger, 1985) and thus are unable to synthesize dopamine and by extrapolation endogenous morphine and derivatives de novo. To explain MIR observed in astrocytes, we propose two hypotheses: 1) as postulated above in the case of neurons, astrocytes may achieve morphine biosynthesis after precursor uptake; and 2) astrocytes are well known to be involved in reuptake of neurotransmitters from the extracellular space (Iversen, 2006), and it can hypothesized that possible uptake of morphine via a transporter exists. Indeed, astrocytes express multidrug-resistant protein (MRP)-1, -3, -4, and -5 as well as glucose transporter (GLUT), which correspond to transporters that are potentially involved in morphine/M6G/M3G/codeine uptake/efflux (Hirrlinger et al., 2002, 2005; Bourasset et al., 2003; Somogyi et al., 2007). In addition, the presence of UGT1A6 in rat astrocytes in primary culture (Suleman et al., 1998; Heurtaux et al., 2006) suggests that after morphine uptake, astrocytes may catabolize morphine into morphine-glucuronides. Moreover, the 
presence of morphine and/or codeine and/or morphine glucuronides in astrocytic foot processes around blood vessels suggests the possibility of uptake from the blood or release into the blood (Brix-Christensen et al., 1997, 2000; Glattard et al., 2010). Finally, our results indicate that astrocytes may be responsible for morphine catabolism in the CNS, mechanisms that now require our attention because of the extensive use of morphine in clinics and as drug of abuse.

\section{MIR and $\boldsymbol{\mu}$ receptors}

In the early 1970s, opioid receptors were discovered in the CNS (Pert et al., 1973). Morphine and its derivative, M6G, preferentially bind the MOR and $\delta$-opioid (DOR) receptors (Matthes et al., 1996; Trescot et al., 2008). MORs are found in both the central and peripheral nervous system. In the brain, the highest densities of MORs are found in the thalamus, the putamen, the substantia nigra, the cortex, the ventral tegmental zone, the nucleus accumbens, and the amygdala (Mansour et al., 1995; Ding et al., 1996). Several endogenous peptides are able to bind the MOR, including $\beta$-endorphin (Li and Chung, 1976; Reisine, 1995), proenkephalin- (enkephalins), and prodynorphinderived (dynorphin-B) peptides (Raynor et al., 1994; Toll et al., 1998). In addition, two other endogenous peptide ligands for MOR, endomorphin-1 and endomorphin-2, have been identified in bovine and human cortex (Zadina et al., 1997; Mizoguchi et al., 2002). Because multiple MOR-binding peptides exist in addition to morphine-like compounds (e.g., in the striatum) (Pierce and Wessendorf, 2000; Furuta et al., 2002), it is difficult to speculate on the individual effects of endogenous alkaloids. Our results have shown the presence of morphine-like compounds in these areas and strongly suggest that endogenous morphine or its derivatives could act as a novel high-affinity endogenous MOR agonists.

\section{Endogenous morphine-like compounds and physiological processes in the central nervous system}

Numerous studies have described the effects of exogenous morphine in the CNS, but without any estimation of effective concentrations inside the synaptic cleft or the extracellular space, it is difficult to speculate on the functions of endogenous morphine by extrapolation from those results. It is also likely that the level of endogenous morphine being produced and secreted can vary with physiological conditions, notably stressful conditions such as fasting (Lee and Spector, 1991; Molina et al., 1995; Goumon et al., 2000; Glattard et al., 2010). Nevertheless, based on the effects of exogenous morphine, coupled with the localization of MOR and the precise dis- tribution of endogenous morphine and/or glucuronides and/or codeine described in this study, several cellular and physiological roles of endogenous morphine-like compounds can be hypothesized.

\section{Motor control}

In the brain, endogenous morphine-like compounds are found in neurons and cell processes involved in motor control, including the red nucleus, the cerebellum, the vestibular nuclei, and the basal ganglia. In the cerebellum, micro-iontophoretic or pneumatic application of morphine to cat Purkinje cells induces either excitatory or inhibitory responses (i.e., either increases or decreases of the firing rates, respectively; Taguchi and Suzuki, 1989; Taguchi et al., 2000). Naloxone reverses excitatory morphine-induced effects, whereas inhibitory effects can be reversed only by the GABA receptor antagonist bicuculline (Taguchi and Suzuki, 1989; Taguchi et al., 2000). In the vestibular nuclei, the spontaneous activity of medial vestibular neurons scattered throughout the nucleus was increased or decreased by ionophoretic application of morphine; this effect was blocked by naloxone (Lin and Carpenter, 1994). These previously published data indicate that exogenous morphine could modulate neuronal activity in brain areas involved in motor control. The presence of endogenous morphine or its derivatives in these specific areas suggests that they may be involved in control of the coordination of movements and postures.

\section{Nociception}

Morphine is one of the most common analgesic drugs used in hospitals; thus the question of the possible roles of endogenous morphine in nociception is unavoidable. Different experiments have suggested that endogenous morphine may be implicated in nociceptive processes. Experiments carried out by Guarna et al. have shown that the injection of antibodies directed against morphine into murine cerebrospinal fluid (a procedure that lowers the level of endogenous morphine in the brain) induced hypersensitivity to heat-associated pain (Guarna et al., 2002; Kieffer and Gaveriaux-Ruff, 2002). In the present study, we have shown the presence of endogenous morphine and/or morphine glucuronides and/or codeine in brain regions thought to be involved in the processing of nociceptive informations (e.g., the PAG and the raphe magnus nuclei). These findings suggest a potential role for endogenous morphine and/or its derivatives in the control of nociception.

\section{Memory}

Exogenous morphine has several effects on hippocampal function. Morphine is able to modulate 
neurotransmission in the hippocampus through inhibition of its GABAergic interneurons by acting on the MORs present on these neurons, leading to an increase in the discharge amplitude of pyramidal neurons in the CA1 zone (Miller and Lupica, 1997), and morphine also modifies the efficiency of glutamatergic synapses by acting on the expression of proteins of the postsynaptic density (i.e., receptors; Moron et al., 2007). Interestingly, endogenous morphine immunoneutralization inhibits learning during periods of stress (e.g., during starvation) (Guarna et al., 2004). In light of all these observations and because this study revealed the presence of MIR in GABAergic interneurons of the dentate gyrus and Ammon's horn, endogenous morphine and/or its derivatives might be involved in the learning processes.

\section{Neurogenesis}

In the brain of adult mammals, the sub-granular zone (SGZ) of the hippocampal dentate gyrus undergoes ongoing neurogenesis (Altman and Das, 1965; Kaplan and Bell, 1984; Cameron et al., 1993; Luskin, 1993). Many studies have been published regarding the effects of morphine on the proliferation of neurons in the SGZ (reviewed in: Sargeant et al., 2007). For example, longterm exposure to morphine (rats and mice; $10 \mathrm{mg} / \mathrm{kg}$ administered intraperitoneally) decreased neurogenesis by a factor of $30 \%$ in the SGZ (Eisch et al., 2000; Mandyam et al., 2004); however, other experiments have shown that morphine stimulated proliferation (Persson et al., 2003a,b). Moreover, in MOR knockout mice, the survival of newly formed neurons in the granular zone of the dentate gyrus increased by over 50\% (Harburg et al., 2007). The presence of endogenous morphine-like compounds in the SGZ may regulate neurogenesis and the survival of neurons.

\section{Alertness}

Startle, or making a quick involuntary movement as in alarm, surprise, or fright, can be regarded as a protective response in mammals. The acoustic startle reflex was prevented by administration of the opioid antagonist naloxone to rats, showing that the opioid system is implicated in acoustic startle gating (Swerdlow et al., 1991). The startle circuit is located in the lower brainstem (Koch et al., 1992), particularly in the caudal pontine reticular nucleus, an area enriched in "morphinergic" terminals. The presence of endogenous morphine-like compounds in the olfactory bulb suggests a role in the response to natural stressors for the endogenous alkaloid.

\section{CONCLUSIONS}

Although no definitive role has yet been attributed to endogenous morphine and its derived compounds found in nervous system tissue, their presence in specific neurons and astrocytes in different areas of the rodent brain cannot be considered simply fortuitous. Endogenous morphine has been shown to be implicated in the regulation of pain as well as in weakening the memory of a nociceptive experience, playing a role similar to its exogenous counterpart. However, the presence of endogenous morphine-like compounds in brain regions that are not usually involved in pain modulation opens exciting perspectives for extending the role and function of this endogenous opiate far beyond analgesic functions.

\section{ACKNOWLEDGMENTS}

We are grateful to Dr. Yannick Bailly, Dr. Guy Roussel, and Mr. Guy Bombarde for technical assistance.

\section{LITERATURE CITED}

Abraira VE, Hyun N, Tucker AF, Coling DE, Brown MC, Lu C, Hoffman GR, Goodrich LV. 2007. Changes in Sef levels influence auditory brainstem development and function. J Neurosci 27:4273-4282.

Altman J, Das GD. 1965. Autoradiographic and histological evidence of postnatal hippocampal neurogenesis in rats. J Comp Neurol 124:319-335.

Arantes C, Nomizo R, Lopes MH, Hajj GN, Lima FR, Martins VR. 2009. Prion protein and its ligand stress inducible protein 1 regulate astrocyte development. Glia 57: 1439-1449.

Atmanene C, Laux A, Glattard E, Muller A, Schoentgen F, Metz-Boutigue MH, Aunis D, Van Dorsselaer A, Stefano GB, Sanglier-Cianferani S, Goumon Y. 2009. Characterization of human and bovine phosphatidylethanolamine-binding protein (PEBP/RKIP) interactions with morphine and morphine-glucuronides determined by noncovalent mass spectrometry. Med Sci Monit 15:BR178-187.

Bianchi E, Alessandrini C, Guarna M, Tagliamonte A. 1993. Endogenous codeine and morphine are stored in specific brain neurons. Brain Res 627:210-215.

Bianchi E, Guarna M, Tagliamonte A. 1994. Immunocytochemical localization of endogenous codeine and morphine. Adv Neuroimmunol 4:83-92.

Boettcher C, Fellermeier M, Boettcher C, Drager B, Zenk MH. 2005. How human neuroblastoma cells make morphine. Proc Natl Acad Sci U S A 102:8495-8500.

Bourasset F, Cisternino S, Temsamani J, Scherrmann JM. 2003. Evidence for an active transport of morphine-6-betad-glucuronide but not P-glycoprotein-mediated at the blood-brain barrier. J Neurochem 86:1564-1567.

Brands A, Munzel PA, Bock KW. 2000. In situ hybridization studies of UDP-glucuronosyltransferase UGT1A6 expression in rat testis and brain. Biochem Pharmacol 59: $1441-1444$.

Brix-Christensen V, Tonnesen E, Sanchez RG, Bilfinger TV, Stefano GB. 1997. Endogenous morphine levels increase following cardiac surgery as part of the antiinflammatory response? Int J Cardiol 62:191-197.

Brix-Christensen V, Goumon Y, Tonnesen E, Chew M, Bilfinger T, Stefano GB. 2000. Endogenous morphine is produced in 
response to cardiopulmonary bypass in neonatal pigs. Acta Anaesthesiol Scand 44:1204-1208.

Broadbelt KG, Paterson DS, Rivera KD, Trachtenberg FL, Kinney HC. 2010. Neuroanatomic relationships between the GABAergic and serotonergic systems in the developing human medulla. Auton Neurosci 154:30-41.

Cameron HA, Woolley CS, McEwen BS, Gould E. 1993. Differentiation of newly born neurons and glia in the dentate gyrus of the adult rat. Neuroscience 56:337-344.

Cardinale GJ, Donnerer J, Finck AD, Kantrowitz JD, Oka K, Spector S. 1987. Morphine and codeine are endogenous components of human cerebrospinal fluid. Life Sci 40: 301-306.

Coffman BL, Rios GR, King CD, Tephly TR. 1997. Human UGT2B7 catalyzes morphine glucuronidation. Drug Metab Dispos 25:1-4.

Coller JK, Christrup LL, Somogyi AA. 2009. Role of active metabolites in the use of opioids. Eur J Clin Pharmacol 65: 121-139.

Ding YQ, Kaneko T, Nomura S, Mizuno N. 1996. Immunohistochemical localization of mu-opioid receptors in the central nervous system of the rat. J Comp Neurol 367: 375-402.

Donnerer J, Cardinale G, Coffey J, Lisek CA, Jardine I, Spector S. 1987. Chemical characterization and regulation of endogenous morphine and codeine in the rat. J Pharmacol Exp Ther 242:583-587.

Eisch AJ, Barrot M, Schad CA, Self DW, Nestler EJ. 2000. Opiates inhibit neurogenesis in the adult rat hippocampus. Proc Natl Acad Sci U S A 97:7579-7584.

Furuta T, Zhou L, Kaneko T. 2002. Preprodynorphin-, preproenkephalin-, preprotachykinin A- and preprotachykinin B-immunoreactive neurons in the accumbens nucleus and olfactory tubercle: double-immunofluorescence analysis. Neuroscience 114:611-627.

Gintzler AR, Gershon MD, Spector S. 1978. A nonpeptide morphine-like compound: immunocytochemical localization in the mouse brain. Science 199:447-448.

Gintzler AR, Levy A, Spector S. 1976. Antibodies as a means of isolating and characterizing biologically active substances: presence of a non-peptide, morphine-like compound in the central nervous system. Proc Natl Acad Sci U S A 73:2132-2136.

Glattard E, Welters ID, Lavaux T, Muller A, Laux A, Zhang D, Schmidt AR, Delalande F, Lavantie BJ, Dirrig-Grosch S, Colin D, Van Dorsselaer A, Aunis D, Metz-Boutigue MH, Schneider F, Goumon Y. 2010. Endogenous morphine levels are increased in sepsis: a partial implication of neutrophils. PLoS One 1:e8791.

Goldstein A, Barrett RW, James IF, Lowney LI, Weitz CJ, Knipmeyer LL, Rapoport H. 1985. Morphine and other opiates from beef brain and adrenal. Proc Natl Acad Sci U S A 82: 5203-5207.

Goumon Y, Bouret S, Casares F, Zhu W, Beauvillain JC, Stefano GB. 2000. Lipopolysaccharide increases endogenous morphine levels in rat brain. Neurosci Lett 293: 135-138.

Goumon Y, Angelone T, Schoentgen F, Chasserot-Golaz S, Almas B, Fukami MM, Langley K, Welters ID, Tota B, Aunis D, Metz-Boutigue MH. 2004. The hippocampal cholinergic neurostimulating peptide, the $\mathrm{N}$-terminal fragment of the secreted phosphatidylethanolamine-binding protein, possesses a new biological activity on cardiac physiology. J Biol Chem 279:13054-13064.

Goumon Y, Muller A, Glattard E, Marban C, Gasnier C, Strub JM, Chasserot-Golaz S, Rohr O, Stefano GB, Welters ID, Van Dorsselaer A, Schoentgen F, Aunis D, Metz-Boutigue $\mathrm{MH}$. 2006. Identification of morphine-6-glucuronide in chromaffin cell secretory granules. J Biol Chem 281: 8082-8089.

Goumon Y, Laux A, Muller A, Aunis D. 2009. Central and peripheral endogenous morphine. An R Acad Nac Farm 75: 389-418.

Grobe N, Lamshoft M, Orth RG, Drager B, Kutchan TM, Zenk MH, Spiteller M. 2010. Urinary excretion of morphine and biosynthetic precursors in mice. Proc Natl Acad Sci U S A 107:8147-8152.

Guarna M, Neri C, Petrioli F, Bianchi E. 1998. Potassiuminduced release of endogenous morphine from rat brain slices. J Neurochem 70:147-152.

Guarna M, Bianchi E, Bartolini A, Ghelardini C, Galeotti N, Bracci L, Neri C, Sonetti D, Stefano G. 2002. Endogenous morphine modulates acute thermonociception in mice. J Neurochem 80:271-277.

Guarna M, Ghelardini C, Galeotti N, Bartolini A, Noli L, Neri C, Stefano GB, Bianchi E. 2004. Effects of endogenous morphine deprivation on memory retention of passive avoidance learning in mice. Int J Neuropsychopharmacol 7: 311-319.

Harburg GC, Hall FS, Harrist AV, Sora I, Uhl GR, Eisch AJ. 2007. Knockout of the mu opioid receptor enhances the survival of adult-generated hippocampal granule cell neurons. Neuroscience 144:77-87.

Hazum E, Sabatka JJ, Chang KJ, Brent DA, Findlay JW, Cuatrecasas P. 1981. Morphine in cow and human milk: could dietary morphine constitute a ligand for specific morphine (mu) receptors? Science 213:1010-1012.

Hedou G, Chasserot-Golaz S, Kemmel V, Gobaille S, Roussel G, Artault JC, Andriamampandry C, Aunis D, Maitre M. 2000. Immunohistochemical studies of the localization of neurons containing the enzyme that synthesizes dopamine, GABA, or gamma-hydroxybutyrate in the rat substantia nigra and striatum. J Comp Neurol 426:549-560.

Herbert RB, Venter H, Pos S. 2000. Do mammals make their own morphine? Nat Prod Rep 17:317-322.

Hesse M. 2002. Alkaloid nature's curse or blessing? Zurich: Wiley-VCH Verlag.

Heurtaux T, Benani A, Moulin D, Muller N, Netter P, Minn A. 2006. Induction of UGT1A6 isoform by inflammatory conditions in rat astrocytes. Neuropharmacology 50:317-328.

Hirrlinger J, Konig J, Dringen R. 2002. Expression of mRNAs of multidrug resistance proteins (Mrps) in cultured rat astrocytes, oligodendrocytes, microglial cells and neurones. J Neurochem 82:716-719.

Hirrlinger J, Moeller H, Kirchhoff F, Dringen R. 2005. Expression of multidrug resistance proteins (Mrps) in astrocytes of the mouse brain: a single cell RT-PCR study. Neurochem Res 30:1237-1244.

Iversen L. 2006. Neurotransmitter transporters and their impact on the development of psychopharmacology. $\mathrm{Br}$ J Pharmacol 147(suppl 1):S82-88.

Jaeger CB. 1985. Cytoarchitectonics of substantia nigra grafts: a light and electron microscopic study of immunocytochemically identified dopaminergic neurons and fibrous astrocytes. J Comp Neurol 231:121-135.

Kaplan MS, Bell DH. 1984. Mitotic neuroblasts in the 9-dayold and 11-month-old rodent hippocampus. J Neurosci 4: 1429-1441.

Kieffer BL, Gaveriaux-Ruff C. 2002. Exploring the opioid system by gene knockout. Prog Neurobiol 66:285-306.

Koch M, Lingenhohl K, Pilz PK. 1992. Loss of the acoustic startle response following neurotoxic lesions of the caudal pontine reticular formation: possible role of giant neurons. Neuroscience 49:617-625.

Kunkel GR, Mehrabian M, Martinson HG. 1981. Contact-site cross-linking agents. Mol Cell Biochem 34:3-13. 
Lee CS, Spector S. 1991. Changes of endogenous morphine and codeine contents in the fasting rat. J Pharmacol Exp Ther 257:647-650.

Li CH, Chung D. 1976. Isolation and structure of an untriakontapeptide with opiate activity from camel pituitary glands. Proc Natl Acad Sci U S A 73:1145-1148.

Lin Y, Carpenter DO. 1994. Direct excitatory opiate effects mediated by non-synaptic actions on rat medial vestibular neurons. Eur J Pharmacol 262:99-106.

Lotsch J. 2005a. Opioid metabolites. J Pain Symptom Manage 29(5 suppl):S10-24.

Lotsch J. 2005b. Pharmacokinetic-pharmacodynamic modeling of opioids. J Pain Symptom Manage 29(5 suppl): S90- 103.

Lotsch J, Geisslinger G. 2001. Morphine-6-glucuronide: an analgesic of the future? Clin Pharmacokinet 40:485-499.

Luskin MB. 1993. Restricted proliferation and migration of postnatally generated neurons derived from the forebrain subventricular zone. Neuron 11:173-189.

Mackenzie PI, Walter Bock K, Burchell B, Guillemette C, Ikushiro S, lyanagi T, Miners JO, Owens IS, Nebert DW. 2005. Nomenclature update for the mammalian UDP glycosyltransferase (UGT) gene superfamily. Pharmacogenet Genomics 15:677-685.

Madbouly KM, Senagore AJ, Delaney CP. 2010. Endogenous morphine levels after laparoscopic versus open colectomy. Br J Surg 97:759-764.

Mandyam CD, Norris RD, Eisch AJ. 2004. Chronic morphine induces premature mitosis of proliferating cells in the adult mouse subgranular zone. J Neurosci Res 76: 783-794.

Mansour A, Fox CA, Burke S, Akil H, Watson SJ. 1995. Immunohistochemical localization of the cloned mu opioid receptor in the rat CNS. J Chem Neuroanat 8:283-305.

Martin-lbanez R, Jenstad M, Berghuis P, Edwards RH, Hioki H, Kaneko T, Mulder J, Canals JM, Ernfors P, Chaudhry FA, Harkany T. 2006. Vesicular glutamate transporter 3 (VGLUT3) identifies spatially segregated excitatory terminals in the rat substantia nigra. Eur J Neurosci 23: 1063-1070.

Matthes HW, Maldonado R, Simonin F, Valverde O, Slowe S, Kitchen I, Befort K, Dierich A, Le Meur M, Dolle P, Tzavara E, Hanoune J, Roques BP, Kieffer BL. 1996. Loss of morphine-induced analgesia, reward effect and withdrawal symptoms in mice lacking the mu-opioid-receptor gene. Nature 383:819-823.

Miller KK, Lupica CR. 1997. Neuropeptide FF inhibition of morphine effects in the rat hippocampus. Brain Res 750: 81-86.

Mizoguchi H, Tseng LF, Suzuki T, Sora I, Narita M. 2002. Differential mechanism of G-protein activation induced by endogenous mu-opioid peptides, endomorphin and betaendorphin. Jpn J Pharmacol 89:229-234.

Molina PE, Hashiguchi Y, Meijerink WJ, Naukam RJ, Boxer R, Abumrad NN. 1995. Modulation of endogenous opiate production: effect of fasting. Biochem Biophys Res Commun 207:312-317.

Moron JA, Abul-Husn NS, Rozenfeld R, Dolios G, Wang R, Devi LA. 2007. Morphine administration alters the profile of hippocampal postsynaptic density-associated proteins: a proteomics study focusing on endocytic proteins. Mol Cell Proteomics 6:29-42.

Mrkusich EM, Kivell BM, Miller JH, Day DJ. 2004. Abundant expression of mu and delta opioid receptor mRNA and protein in the cerebellum of the fetal, neonatal, and adult rat. Brain Res Dev Brain Res 148:213-222.

Muller A, Glattard E, Taleb O, Kemmel V, Laux A, Miehe M, Delalande F, G. R, Van Dorsselaer A, Metz-Boutigue MH,
Aunis D, Goumon Y. 2008. Endogenous morphine in SHSY5Y cells and the mouse cerebellum. PLoS One3. Epub: www.plosone.org/doi/pone.0001641.

Nagano E, Yamada H, Oguri K. 2000. Characteristic glucuronidation pattern of physiologic concentration of morphine in rat brain. Life Sci 67:2453-2464.

Neri C, Guarna M, Bianchi E, Sonetti D, Matteucci G, Stefano GB. 2004. Endogenous morphine and codeine in the brain of non human primate. Med Sci Monit 10:MS1-5.

Neri C, Ghelardini C, Sotak B, Palmiter RD, Guarna M, Stefano G, Bianchi E. 2008. Dopamine is necessary to endogenous morphine formation in mammalian brain in vivo. J Neurochem 106:2337-2344.

Okura T, Saito M, Nakanishi M, Komiyama N, Fujii A, Yamada S, Kimura R. 2003. Different distribution of morphine and morphine-6 beta-glucuronide after intracerebroventricular injection in rats. Br J Pharmacol 140:211-217.

Paxinos G, Franklin KBJ. 1997. The mouse brain in stereotaxic cooordinates. London: Elsevier Academic Press.

Persson Al, Thorlin T, Bull C, Eriksson PS. 2003a. Opioidinduced proliferation through the MAPK pathway in cultures of adult hippocampal progenitors. Mol Cell Neurosci 23:360-372.

Persson Al, Thorlin T, Bull C, Zarnegar P, Ekman R, Terenius L, Eriksson PS. 2003b. Mu- and delta-opioid receptor antagonists decrease proliferation and increase neurogenesis in cultures of rat adult hippocampal progenitors. Eur J Neurosci 17:1159-1172.

Pert CB, Pasternak G, Snyder SH. 1973. Opiate agonists and antagonists discriminated by receptor binding in brain. Science 182:1359-1361.

Pierce TL, Wessendorf MW. 2000. Immunocytochemical mapping of endomorphin-2-immunoreactivity in rat brain. J Chem Neuroanat 18:181-207.

Poeaknapo C, Schmidt J, Brandsch M, Drager B, Zenk MH. 2004. Endogenous formation of morphine in human cells. Proc Natl Acad Sci U S A 101:14091-14096.

Raynor K, Kong H, Chen Y, Yasuda K, Yu L, Bell GI, Reisine T. 1994. Pharmacological characterization of the cloned kappa-, delta-, and mu-opioid receptors. Mol Pharmacol 45: 330-334.

Reisine T. 1995. Opiate receptors. Neuropharmacology 34: 463-472.

Sargeant TJ, Day DJ, Mrkusich EM, Foo DF, Miller JH. 2007. $\mathrm{Mu}$ opioid receptors are expressed on radial glia but not migrating neuroblasts in the late embryonic mouse brain. Brain Res 1175:28-38.

Soliman HM, Melot C, Vincent JL. 2001. Sedative and analgesic practice in the intensive care unit: the results of a European survey. Br J Anaesth 87:186-192.

Somogyi AA, Barratt DT, Coller JK. 2007. Pharmacogenetics of opioids. Clin Pharmacol Ther 81:429-444.

Spector S, Kantrowitz JD, Oka K. 1985. Presence of endogenous morphine in toad skin. Prog Clin Biol Res 192: 329-332.

Stefano GB, Goumon Y, Casares F, Cadet P, Fricchione GL, Rialas C, Peter D, Sonetti D, Guarna M, Welters ID, Bianchi E. 2000. Endogenous morphine. Trends Neurosci 23: 436-442.

Stefano GB, Cadet P, Kream RM, Zhu W. 2008. The presence of endogenous morphine signaling in animals. Neurochem Res 33:1933-1939.

Suleman FG, Abid A, Gradinaru D, Daval JL, Magdalou J, Minn A. 1998. Identification of the uridine diphosphate glucuronosyltransferase isoform UGT1A6 in rat brain and in primary cultures of neurons and astrocytes. Arch Biochem Biophys 358:63-67. 
Swerdlow NR, Caine SB, Geyer MA. 1991. Opiate-dopamine interactions in the neural substrates of acoustic startle gating in the rat. Prog Neuropsychopharmacol Biol Psychiatry 15:415-426.

Taguchi K, Suzuki Y. 1989. Effects of microiontophoreticallyapplied morphine on the Purkinje cell in the cerebellum of the cat. Neuropharmacology 28:235-242.

Taguchi K, Abe K, Chyuma T, Kato M, Shigenaga T, Kushida K, Chikuma T. 2000. Effects of microiontophoretically-applied opioid peptides on Purkinje cells in the cat cerebellum. Acta Pharmacol Sin 21:877-884.

Toll L, Berzetei-Gurske IP, Polgar WE, Brandt SR, Adapa ID, Rodriguez L, Schwartz RW, Haggart D, O'Brien A, White A, Kennedy JM, Craymer K, Farrington L, Auh JS. 1998. Standard binding and functional assays related to medications development division testing for potential cocaine and opiate narcotic treatment medications. NIDA Res Monogr 178:440-466.

Trescot AM, Datta S, Lee M, Hansen H. 2008. Opioid pharmacology. Pain Physician 11(2 suppl):S133-153. von Bohlen Und Halbach O. 2007. Immunohistological markers for staging neurogenesis in adult hippocampus. Cell Tissue Res 329:409-420.

Walker JF. 1964. Formaldehyde, 3rd ed. New York: Reinhold Publishing. p 486.

Weitz CJ, Lowney LI, Faull KF, Feistner G, Goldstein A. 1986. Morphine and codeine from mammalian brain. Proc Natl Acad Sci U S A 83:9784-9788.

Weitz CJ, Faull KF, Goldstein A. 1987. Synthesis of the skeleton of the morphine molecule by mammalian liver. Nature 330:674-677.

Zadina JE, Hackler L, Ge LJ, Kastin AJ. 1997. A potent and selective endogenous agonist for the mu-opiate receptor. Nature 386:499-502.

Zhang Y, Pan YX, Kolesnikov Y, Pasternak GW. 2006. Immunohistochemical labeling of the mu opioid receptor carboxy terminal splice variant mMOR-1B4 in the mouse central nervous system. Brain Res 1099:33-43.

Zhu W, Bilfinger TV, Baggerman G, Goumon Y, Stefano GB. 2001. Presence of endogenous morphine and morphine 6 glucuronide in human heart tissue. Int $\mathrm{J}$ Mol Med 7: 419-422. 